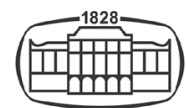

AKADÉMIAI KIADÓ

Archaeologiai Értesítő

$146(2021) 197-224$

DOI:

$10.1556 / 0208.2021 .00010$

๑) 2021 A szerzö

\section{Módszertan}

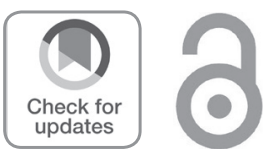

\title{
A kerámiaedények formázásának technológiai vizsgálata: Áttekintés a módszertan alapjairól és alkalmazásáról
}

\author{
Solnay Eszter ${ }^{1 *}$ (D)
}

${ }^{1}$ Eötvös Loránd Tudományegyetem Bölcsészettudományi Kar, Régészettudományi Intézet; 1088 Budapest, Múzeum körút 4/B

Kézirat beérkezett: 2021. május 25. Kézirat elfogadva: 2021. június 12.

\section{ABSZTRAKT}

A kerámiaedények formázásának technológiai vizsgálata egy antropológiai megközelítésű kutatási módszer, mellyel feltérképezhetők a kerámiaegyüttesek mögött húzódó készítési tradíciók és szociális mechanizmusok. Jelen tanulmány rövid áttekintést nyújt a metódus alapjairól, valamint bemutat néhány alapvető, fazekaskorong nélküli formázási technikát és ezek lehetséges azonosítási nyomait a régészeti leletanyagban.

\section{KULCSSZAVAK}

etnoarcheológia, technológiai vizsgálat, edényformázás, korongolatlan edények, kora rézkor

\section{ABSTRACT}

The technological analysis of ceramic fashioning is an anthropological methodological approach, which is able to detect technical traditions and social mechanisms through the analysis of the ceramic assemblages. This paper provides a review of the methodological basis and introduces some basic fashioning techniques without a potter's wheel and their possible identification traces in the archaeological assemblages.

\section{KEYWORDS}

ethnoarchaeology, technological analysis, ceramic fashioning, potteries shaped without a potter's wheel, Early Copper Age

\section{BEVEZETÉS}

Minden kézzel készített kerámiaedény mögött áll egy fazekas, aki azt létrehozta az edényről alkotott mentális kép alapján, saját tudását és képességeit felhasználva. Ennek következtében minden edény magán hordoz olyan nyomokat, melyek az őt készítő fazekas motorikus és kognitív készségeire, vagyis elméleti és gyakorlati felkészültségére utalnak.

Ezt az alapvetést használja fel a kerámiaedények formázásának technológiai vizsgálata, ${ }^{1}$ mely a technikák antropológiáját kutató francia iskolában (Anthropologie des Techniques) gyökerezik. ${ }^{2}$ A módszertan célja szociális mechanizmusokat tükröző kerámiaformázási eljárások azonosítása és technológiai tradíciók rekonstruálása a régészeti edények technikai vizsgálatán keresztül. Ehhez pedig az etnoarcheológiai kutatásokat használja referenciaként, párhuzamba állítva az etnográfiai és a régészeti kontextusban tett technológiai megfigyeléseket.

A kerámiák formázásának technológiai megközelítésű vizsgálata mára nemzetközileg elismert iskolává vált, azonban a hazai régészetben még nagyon kevéssé van jelen. Ez szükségessé teszi a téma magyar nyelvü összefoglalását, valamint az alapvető fogalmak magyar nyelvü

* Levelező szerző:

E-mail: eszter.solnay@gmail.com

${ }^{1}$ Jelen cikk az edények technológiai vizsgálatán belül csak a formázás analízisével foglalkozik, így nem tér ki más kutatási módszerekre - például petrográfiai vizsgálatokra -, melyek szintén az edények technológiai vizsgálatai közé tartoznak.

${ }^{2}$ Leroi-Gourhan 1945; Mauss 1947; Latour-Lemonnier 1994. 
meghatározását. Jelen tanulmány erre tesz kísérletet, áttekintve a módszertan alapjait, és bemutatva az alkalmazásának lehetőségét a korongolatlan, kézzel formázott edények esetében.

\section{A KUTATÁS NEMZETKÖZI ÉS HAZAI HELYZETE}

\section{A múveletsor koncepciójának kialakulása}

A kerámiaformázás technológiai vizsgálatának módszertana a 20. századi francia etnológiai kutatásokban gyökerezik, a műveletsor (chaîne opératoire) ${ }^{3}$ koncepciójának felvázolásával és kiterjedt kutatásával. ${ }^{4}$

A 20. század első felében Marcel Mauss, francia szociológus, elsőként hangsúlyozta a technikák mélyebb tanulmányozásának és a különböző készítési fázisok vizsgálatának fontosságát. ${ }^{5}$ Ez adott inspirációt számos etnológusnak, köztük Marcel Maget-nek és André Leroi-Gourhan-nak. M. Maget 1953-ban bevezette a gyártási sor (chaîne de fabrication) kifejezést, javasolva a készítési tevékenység különböző szinteken történő vizsgálatát, illetve fázisokra és elemi gesztusokra $^{6}$ történő bontását. ${ }^{7}$ A. Leroi-Gourhan az 1943-ban, illetve 1945-ben kiadott kétkötetes munkájában elemezte az alapvető - például mezőgazdasági, vadászati vagy ételkészítési - technikákat, és rendszerezte a megvalósításukhoz a különböző kultúrákban használt mozdulatokat (mouvements) és eszközöket (moyens d'action). ${ }^{8}$ Majd az 1964-1965-ben megjelent, szintén kétkötetes monográfiájában az emberi kultúra és a technikák fejlődésének kapcsolatát kutatta, ${ }^{9}$ melyben megfogalmazta a müveletsor következő koncepcióját: „A technika egyszerre mozdulat és eszköz, amelyek láncolatba szerveződnek egy valódi szintaxis által, amely egyidejűleg rögzítettséget és hajlékonyságot is ad a müveletek sorozatainak. A müveleti szintaxist a memória javasolja, s az agy és az anyagi miliő között születik meg." ${ }^{10}$ A megfogalmazást később ki is bontotta, ${ }^{11}$ azonban - ahogy arra később számos kutató felhívja a figyelmet - nem adta meg a múveletsor konkrét definícióját. ${ }^{12} \mathrm{Ez}$ vezetett a későbbi kutatás számára azokhoz a vitákhoz, hogy mit értünk a műveletsor fogalma alatt. ${ }^{13}$

A müveletsor koncepcióját francia etnológusok egy csoportja pontosította és fejlesztette tovább, akiknek két vezető

\footnotetext{
${ }^{3}$ A magyar kifejezést javasolta: HoLló et al. 2001, 51.

${ }^{4}$ A kutatás történetére nézve lásd: Pelegrin et al. 1988; Holló et al. 2001; Audouze-Karlin 2017; Delage 2017; Mester 2019.

${ }^{5}$ Mauss 1947; Mauss 2000.

${ }^{6}$ A magyar kifejezéseket javasolta: Holló et al. 2001, 51.

${ }^{7}$ Maget 1953.

${ }^{8}$ Leroi-Gourhan 1943; Leroi-Gourhan 1945.

${ }^{9}$ Leroi-Gourhan 1964; Leroi-Gourhan 1965.

${ }^{10}$ Leroi-Gourhan 1964, 164. Fordította Mester Zsolt: Mester 2019, 257.

${ }^{11}$ Leroi-Gourhan 1965, 9-62.

${ }^{12}$ AudouZe-Karlin 2017, 3; Mester 2019, 257.

${ }^{13}$ Roux 2010, 102; Mester 2019, 257.
}

alakja Robert Cresswell és Hélène Balfet volt. ${ }^{14}$ A R. Cresswell vezette kutatócsoport folyóirata, a Techniques \& Culture 1976-ban jelentette meg első lapszámát, melyben meghatározták a fó témájukat; a müveletsorok különböző szintjeinek és nézőpontjainak vizsgálatát. ${ }^{15}$ Emellett ők kutatták először mélyrehatóbban a technikai folyamatok és a szociális kapcsolatok viszonyát, ${ }^{16}$ melynek fontos szerepe van a kerámiaformázás technológiai vizsgálatában is. H. Balfet pedig 1975-ös munkájában a különböző műveletsorok kapcsolatát elemezte, ${ }^{17}$ majd az 1990-es évek elején szerkesztése alatt jelent meg egy kötet, mely összefoglalja a müveletsor kutatásainak föbb irányait, kérdéseit és problémáit. ${ }^{18} \mathrm{R}$. Cresswell és H. Balfet iskolájának követője volt többek között Pierre Lemonnier, aki tovább pontosította a műveletsor definícióját. ${ }^{19} \mathrm{Az}$ Université Paris 1 Panthéon-Sorbonne-on tartott szemináriumainak köszönhetően pedig az elmélet az 1980-as években elkezdett elterjedni az őskoros kutatók körében is. ${ }^{20}$

A 20. századi kutatások nyomán a műveletsor kifejezés ma minden olyan folyamatra használható, amely során müveletek sorozatával egy kiindulási alapból egy kész terméket hozunk létre. Ez egyrészt vonatkozhat a teljes készítési folyamatra, amikor a nyersanyagból egy kész terméket hozunk létre. ${ }^{21}$ Ilyen lehet például a természetes lelőhelyén található agyag (kiindulási alap) és a kész edény (kész termék) között leírható müveletek sorozata. Másrészt vonatkozhat a készítési folyamat egy részére, ${ }^{22}$ például az előkészített agyag megformázására. Ebben az esetben a fogalom a formázásra elökészített agyagmassza (kiindulási alap) és a megformázott, de még égetetlen, díszítetlen edény (kész termék) között leírható műveletek sorozatát takarja.

\section{Az edényformázás technológiai szemléletű kutatásának kialakulása}

A kerámiák formázásának technológiai vizsgálata a műveletsor koncepciójából nőtt ki és vált önálló irányzattá az elmúlt évtizedek során. Az egyik első ilyen munka a korábban említett H. Balfet nevéhez kötődik. Ö a technikák antropológiáját vizsgáló korai etnográfiai munkák nyomán már 1953-ban a párizsi Musée de l'Homme összehasonlító technológiai laboratóriumában fellelhető különböző régészeti korú edényeken tudta a szemmel látható nyomok - vagyis makronyomok - alapján azonosítani a hurkák összeillesztésével történő kerámiaformázást, a hurkatechnikát. ${ }^{23} \mathrm{Az}$ általa alkalmazott, technológiai szemléletű kerámiaanalízis módszertanát 1966-ban részletesen publikálta is, kitérve a formá-

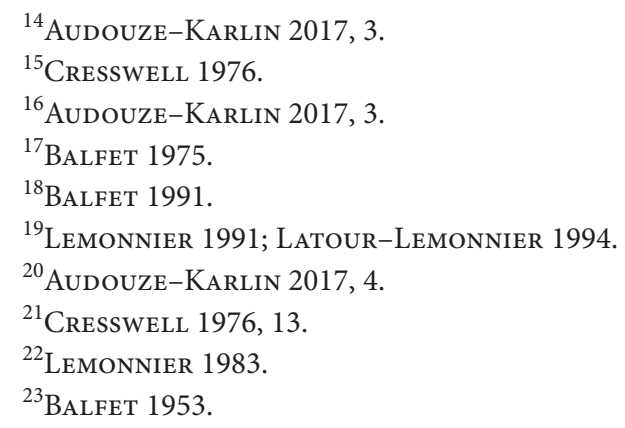


zás azonosítására. ${ }^{24}$ Viszont néhány hasonló, korai munkától eltekintve a régészeti edények technológiai vizsgálata még több évtizedet váratott magára.

Azonban a régészeti kutatásokkal ellentétben a müveletsor koncepciója a francia etnográfiai megfigyelések, ${ }^{25}$ így a kerámiakutatások fontos része lett már a 20. század közepén. Számos tanulmány jelent meg kortárs fazekasok által használt készítési technikákról, például $\mathrm{H}$. Balfet tollából az észak-afrikai kerámiakészítésről. ${ }^{26}$ A megfigyelésekben egyre nagyobb hangsúlyt kapott a formázási technikák és folyamatok részletes leírása, valamint a továbbadásuk módjának és a szociális kapcsolatokkal való összefüggéseiknek az elemzése. $^{27}$ Ezek a kutatások nélkülözhetetlen alapot nyújtottak a régészeti korú kerámiák formázástechnológiai vizsgálatának kialakulásához, referenciaként szolgálva a különböző technikák azonosításához. Ugyanis számos, a kortárs fazekasoknál megfigyelt szociális jelenség, ${ }^{28}$ illetve formázási technika párhuzamba hozható a régészeti korokban megfigyeltekkel, így támpontot nyújt a régészeti edények formázási módjainak elemzéséhez és az eredményeik értelmezéséhez.

A műveletsor koncepciójának francia kutatók által történő kidolgozásával párhuzamosan az angolszász régészetben is elkezdődött a kerámiák készítésének részletes vizsgálata. Az egyik első, nagy hatású összefoglaló kötetet Anna O. Shepard publikálta 1956-ban, mely részletesen foglalkozik a kerámiák nyersanyagának fizikai és kémiai tulajdonságaival, készítésének különböző lépéseivel és lehetséges vizsgálati módszereivel. ${ }^{29}$ A monográfia széles körben ismertté vált és kiindulási pontként szolgált a kerámiák készítésével foglalkozó kutatások számára, mely további jelentős tanulmányok megjelenését eredményezte. ${ }^{30}$ Ezek közül kiemelhető Owen S. Rye 1981-es munkája, melyben számos fejezeten át foglalkozik az edények formázási technikáival, valamint az egyes technikák lehetséges makronyomaival. ${ }^{31}$ Ezek a kötetek szintén kulcsfontosságúak a régészeti korú kerámiák formázástechnológiai vizsgálatához, mivel a technikák, illetve bizonyos esetekben azok nyomainak részletes leírása segít azonosítani a régészeti edények formázásának módját.

Ezeket követően, a 20. század utolsó évtizedeiben, a müveletsor koncepciójának kidolgozása, az ezen alapuló etnográfiai kerámiakutatások, illetve az angolszász kerámiakészítési vizsgálatok alapjain őskoros francia kutatók kidolgozták a régészeti kerámiák formázásának technológiai megközelítésű analízisét. Ennek a módszertannak egyik megalapozója Valentine Roux etnoarcheológus, aki 1994ben publikálta egyik korai tanulmányát a korongolás definíciójáról és azonosításáról, melyben a vizsgálati módszertan

\footnotetext{
${ }^{24}$ BALFET 1966.

${ }^{25}$ Delage 2017, 163-165.

${ }^{26}$ BALFET 1965; BALFET 1977.

${ }^{27}$ Pl. Gallay 1992; Gosselain 1992.

${ }^{28} \mathrm{Pl}$. a formázási hagyományok továbbadása.

${ }^{29}$ SHEPARD 1956.

${ }^{30}$ Rice 1987; Rye 1981; Orton et al. 1993.

${ }^{31}$ RYE 1981.
}

számos olyan alapvető elemét és kifejezését foglalta össze, amik érvényesek a nem korongolt edények elemzésére is. ${ }^{32}$ Azóta is számos jelentős módszertani munka jelent meg a tollából. A néhány éve francia, majd angol nyelven megjelent monográfiája a kutatási módszer egyik legjelentősebb összefoglalásának tekinthető, melyben tárgyalja az edénykészítés különböző fázisainak - különös tekintettel a formázás technológiai megközelítésű elemzését, kitérve a különböző technikák jellemzőire és azok makro-, és esetenként mikronyomaira. $^{33}$

A módszertan egy másik fontos képviselöje François Giligny, aki szintén a múlt század vége óta foglalkozik a témával. Már az 1993-ban megvédett doktori disszertációjában végzett formázástechnikai megfigyeléseket a Jura tavak környéki neolitikus lelőhelyek edényein. ${ }^{34}$ Valamint a módszertan fiatal kutatókkal való megismertetésében is fontos szerepe van F. Giligny-nek az Université Paris 1 PanthéonSorbonne-on, valamint V. Roux-nak az Université Paris 10 Nanterre-en végzett oktatómunkájának köszönhetően.

A módszertani irányzat az elmúlt évtizedekben meghatározó iskolává nőtte ki magát a francia kutatásban. Ezt jól mutatja a Les Nouvelles de l'archéologie folyóirat 2010-ben megjelent száma, F. Giligny és Sophie Méry szerkesztésében, melyben számos francia kutató ismerteti a kerámiakészítési műveletsor vizsgálati megközelítéseit alkalmazó friss doktori disszertációját, ${ }^{35}$ illetve több évtizedes munkáját. ${ }^{36}$ A kiadvány rámutat a módszer jelentőségére és különböző területeken történő alkalmazására, valamint jól illusztrálja a müveletsor koncepciójának egyre szélesebb körben való elterjedését az őskori kerámiakutatásban. A módszertan elterjedése és a nemzetközi régészetben való ismertté válása pedig az utóbbi évek egyik fontos feladatává tette a nevezéktan és a pontos vizsgálati metódus rögzítését, illetve egységesítését. $^{37}$

\section{Az edények formázásának technológiai szemléletú kutatása a Kárpát-medencei őskorban}

A Kárpát-medence őskorának kutatásában idáig kevés olyan publikáció született, amely ezt a módszertani iskolát követi, jóllehet az ilyen irányú kutatásokkal gyakran összefonódó petrográfiai, stilisztikai és a használattal, illetve a fazekastudás szintjével/szakértelmével összefüggő vizsgálatok ismertek. ${ }^{38}$ Fontos kiemelni még Gucsi László munkásságát, aki keramikus tudásának köszönhetően elsőként azonosított Kárpát-medencei rézkori és bronzkori edényformázási tech-

\footnotetext{
${ }^{32}$ Roux 1994.

${ }^{33}$ Roux 2016; Roux 2019

${ }^{34}$ GiLignY 1993.

${ }^{35}$ Ard 2010; Dupont-Delaleuf 2010; Gomart 2010; Manem 2010; VisSEYRIAS 2010.

${ }^{36}$ Giligny 2010; Livingstone Smith 2010; Martineau 2010; MéRY et al. 2010; Roux 2010.

${ }^{37}$ LePÈre 2014; Roux 2017; Roux 2019.

${ }^{38}$ Például Kreiter 2007; Szilágyi 2015; Szakmány-Nagy 2017; GuCsi-Szabó 2018; Sofaer-Budden 2013.
} 
nikákat. ${ }^{39}$ Megállapításai fontos referenciaként szolgálnak a hazai kerámiaanyag technológiai megközelítésű vizsgálatához is.

Az első olyan hazai munkák, amelyek a francia iskola által kidolgozott formázástechnológiai vizsgálati módszertant követték, neolitikus és rézkori lelőhelyek elemzéséhez kötődnek. A nyugat-európai Vonaldíszes kultúra kerámiáinak formázástechnológiáját vizsgáló disszertációját ${ }^{40}$ követően Louise Gomart a délkelet-európai neolitikum formázási hagyományait kezdte kutatni. Ennek keretében négy Kárpát-medencei neolitikus lelőhely - Balatonszárszó-Kiserdei-dülő, Nagykörü-Tsz. Gyümölcsös, Polgár-Ferenci-hát és Vörs-Máriaasszony-sziget - edényeinek formázását elemezte, ${ }^{41}$ melyek a petrográfiai, stilisztikai és tipológiai elemzésekkel kiegészülve fontos lépésként szolgáltak a Kárpát-medencei neolitikumban zajló szociális mechanizmusok megértéséhez. ${ }^{42}$

L. Gomart munkája adott inspirációt a későbbi hazai kutatásoknak, köztük Füzesi Andrásnak, aki L. Gomart és Gucsi L. megállapításait felhasználva a késő neolitikus Öcsöd-Kovácshalom kerámiaegyüttesét vizsgálta technológiai szempontból. ${ }^{43}$ Legújabban pedig mesterszakos szakdolgozatom keretében végeztem formázástechnológiai vizsgálatokat a kora rézkori Tiszagyenda-Vágott-halomról (Nagykunsági-tározó 17. lelőhely) ${ }^{44}$ és Polgár-Király-ér-partról (Polgár 1. lelőhely). Ebben az L. Gomart által is alkalmazott, itt ismertetendő francia kutatási módszertant követtem.

\section{A KERÁMIAFORMÁZÁS VIZSGÁLATA}

A kerámiakészítés müveletsora öt nagyobb szakaszra bontható (1. kép): ${ }^{45}$

1. Elsőként a nyersanyag begyüjtése és átalakítása, mely során kitermelik az agyagos üledéket, majd megtisztítják a szennyeződésektől, szükség szerint soványítják, így létrehozva a formázható agyagpasztát, amit utána pihentetnek.

2. Ezt követi a formázás, ahol az elökészített pasztát edénnyé alakítják.

3. Ezután következhet a készre dolgozás, illetve felületkezelés, melyeket gyakran egy lépésként kezelnek, mivel mindkettő célja megváltoztatni a paszta legfelső rétegének külső vagy belső állapotát.

4. A műveletsor következő eleme a díszítés.

5. Az utolsó szakasz pedig a szárítás utáni égetés, mely során az edény tulajdonságai és a belső szerkezete visszafordíthatatlanul átalakul.

${ }^{39}$ GUCSI 2000; GUCSI 2006; GUCSI 2009

${ }^{40}$ Gomart 2014 b.

${ }^{41}$ Gomart 2014a.

${ }^{42}$ Gomart et al. 2020; Kreiter et al. 2017; Marton et al. 2020.

${ }^{43}$ FÜZESI 2019.

${ }^{44}$ Solnay in press.

${ }^{45}$ Rye 1981; Gosselain 2002; Gosselain-Livingstone Smith 2005; Arnold 2006; Doosselaere 2010; Gallay 2012; Lepère 2014; Roux 2017.

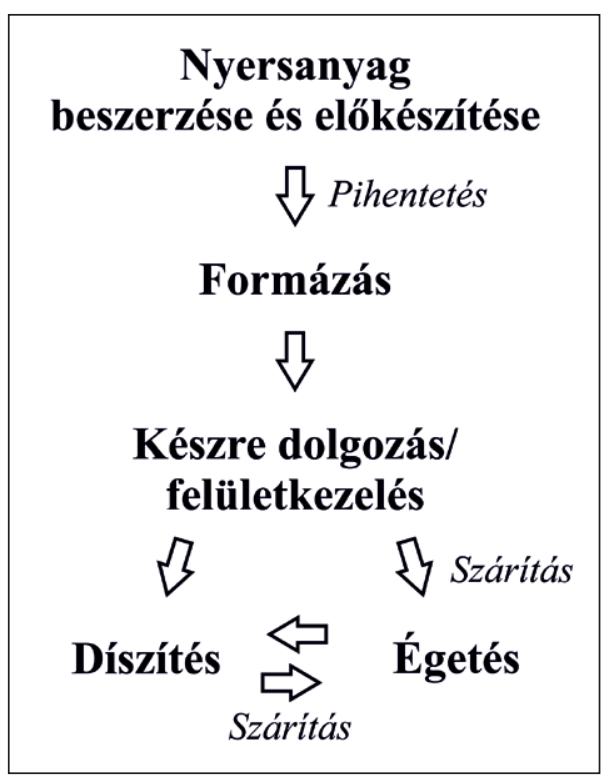

1. kép. A kerámiakészítés múveletsorának alapvető szakaszai

Fig. 1. The main steps of the chaîne opératoire of ceramic fashioning

A készítés egyes szakaszait pedig egyaránt különböző ideig tartó száradási folyamat előzheti meg, illetve követheti.

A kerámiák technológiai megközelítésü tanulmányozásában kiemelkedő szerepet foglal el a formázás vizsgálata, mert az nehezebben változik, mint a műveletsor többi eleme. ${ }^{46}$ Ennek oka a tanulás folyamatában keresendő, ${ }^{47}$ melynek során a tanuló megfigyeli és lemásolja a tanító edénykészítési módját. A folyamat végére a tanuló kerámiaformázási módja automatizálódik, rögzülnek a tevékenységhez szükséges motorikus és kognitív készségek, melyeken később már nehezen tud változtatni. A kerámiakészítés módja minden esetben gyakorlati közösségeken (communautés de pratique) belül adódik tovább, azaz olyan szociális csoportokon belül, melyeket a közös technikai gyakorlat köt össze. Ezek természete és struktúrája sokféle lehet, például család, klán, háztartás, etnolingvisztikai csoport. ${ }^{48}$ Így a csoport tagjai a tanulás során szociális identitást is elsajátítanak, vagyis a készítés módja gyakran egyet jelent számukra a szociális kötelékekkel és az összetartozással, melynek fontos a megörzése és továbbadása. ${ }^{49}$ Mivel a készítési módok folyamatosan továbbadódnak a szociális alapon szerveződő gyakorlati közösségeken belül, hosszú távon kerámiaformázási tradíciókat lehet megfigyelni. ${ }^{50}$ A formázási tradíció (tradition de façonnage) a készítés módjának hosszú távon történő továbbadása, melyeknek az antropológiai jelentésén túl nincsen kulturális

\footnotetext{
${ }^{46}$ Gosselain 2002, 26; Gelbert 2003, 53-59;

${ }^{47}$ BRIL 2002.

${ }^{48}$ Gosselain 2002, 23-27; Roux 2010, 4, 6.

${ }^{49}$ Gosselain 2002, 26; Gosselain-Livingstone Smith 2005, 41; Roux 2010, 6.

${ }^{50}$ Gosselain-Livingstone Smith 2005, 41-42; Roux 2010, 6; Gomart 2014a, 154; GiLigny 2015, 73.
} 
vagy egyéb aspektusa, tehát nem érthető bele semmilyen kulturális, nyelvi, vérségi vagy egyéb típusú összetartozás. Így ezek elkülönítésének alapját kizárólag a formázási technikák különbözösége adja, nem lehet összevonni a kerámiák további jellemzőivel, például formával vagy díszítéssel. ${ }^{51}$

A módszertan ismertetése előtt elengedhetetlen tisztázni az edények formázásával kapcsolatos alapfogalmakat. A kerámiák formázása különböző fázisokból (phase) áll, mely során az edény egyes részei megformálásra kerülnek. ${ }^{52} \mathrm{~A}$ morfológia alapján három alapvető fázis különböztethető meg: 1) talp (base), 2) test (corps) és 3) perem (lèvre). ${ }^{53}$ Azonban a vizsgált kerámiaegyüttestől függően további fázisokat is elkülöníthetünk, például csőtalpat, nyakat, fület. Egy fázisnak két sikeres szakaszból (étape) kell állnia az elképzelt forma megvalósítása érdekében: 1) az elsődleges formázásból (façonnage primaire) - más néven kinagyolásból (ébauchage), ennek során az edény megkapja az alapvető alakját; 2) a másodlagos formázásból (façonnage secondaire) - más néven a megformálásból (préformage), amely alatt az edény elnyeri a pontos formáját. ${ }^{54}$

Minden egyes kerámiának megvan a saját formázási metódusa (méthode), mely bizonyos funkcionális müveletek rendezett sorrendjeként definiálható. Tehát a nyersanyag megformálásának kezdetétől a végleges edényforma létrejöttéig történő formázási cselekvések sora. A formázási metódust fogások (geste) sorozatával hajtják végre, vagyis a test olyan szándékos vagy akaratlan mozdulatainak sorrendjével, mellyel az agyagpasztából kész edényt formáznak. Ennek megvalósításához különböző formázási technikák (technique) - vagyis az agyag átalakításának fizikai módjai - használhatóak. ${ }^{55}$ A formázási technikák alapvetően két nagy csoportra oszthatóak az energiaforrás típusa szerint: 1) a körkörös forgató energia (énergie cinétique rotative), azaz korongolás nélkül, 2) illetve a korongolással formázott edényekre. ${ }^{56}$ Ez a kettősség mind az elsődleges, mind a másodlagos formázás esetében fennállhat. Jelen tanulmány a korongolatlan, vagyis a kézzel formázott edények vizsgálatára fókuszál.

A formázási technikák azonosításának alapja az edényen található készítési nyomok makroszkopikus megfigyelése, a makronyomok azonosítása (2. kép). Ez elsősorban a felület topográfiájának (topographie de la surface), a falvastagság változásának (variation d’épaisseur des parois), a törésvonalak rendszerének (réseau des fractures) és a belső struktúrának (structure interne) a vizsgálatát jelenti. Ezeket részben az edény 1) külső és belső, horizontális felületén (plan tangentiel/plan équatorial/en surface) és 2) törésfelületén (plan radial/en coupe) lehet azonosítani (3. kép). ${ }^{57}$

\footnotetext{
${ }^{51}$ Gelbert 2003, 43; Gomart 2014b, 43.

${ }^{52}$ Roux 2017, 63.

${ }^{53}$ VAN DER LEEUW 1993.

${ }^{54}$ Rye 1981, 62; Roux 1994, 46; Martineau 2000, 116; Gosselain 2002, 80; Pierret 2002, 16-17; Livingstone Smith 2007, 94-95; Gallay 2012, 61; Roux 2017, 64.

${ }^{55}$ Roux 2017, 63.

${ }^{56}$ Roux 2017, 79.

${ }^{57}$ Livingstone Smith 2007, 112-129; Doosselaere 2010, 181 222; GoMART 2014b, 44-45; Roux 2017, 179-187.
}

A makronyomok megfigyelésének előnye, hogy nemcsak egész edényeken, hanem a régészeti leletanyagban leggyakrabban előforduló jellegzetes edénytöredékeken is elvégezhető és értelmezhető. Ezért elsőként fontos a vizsgált leletanyagban a minimum edényszám meghatározása, tehát az edények összes előkerült töredékének megtalálása és összeillesztése, amennyiben a technológiai elemzés előtt még nem rakták össze őket. ${ }^{58}$ A jellegzetes formai jegyeket hordozó töredékeknek köszönhetően így számos edény formai típusa rekonstruálható lesz, annak ellenére, hogy az edény bizonyos részei nem kerültek elő. Ezt követően minden jellegzetes ép vagy töredékes kerámia összes ismert formázási fázisának - vagyis az edény összes ismert részének - minden makronyomát egy adatlapon rögzíteni, kódolni, illetve fotózni vagy rajzolni kell (28-30. képek). ${ }^{59}$ Végül, az azonosított makronyomok alapján értelmezni kell az edények formázási technikáját és metódusát, referenciaként felhasználva a rendelkezésre álló számos etnográfiai, régészeti és kísérleti munkát. ${ }^{60}$

Fontos azonban megjegyezni, hogy a vizsgálati folyamatot nagyban befolyásolják egyrészt az edények egyéb tulajdonságai, például a felületkezelés vagy díszítés. Ezek minden esetben a formázást követő készítési szakaszok, ${ }^{61}$ melyek megváltoztatják az edény felületének állapotát, így befolyásolják a formázás makronyomainak azonosíthatóságát. Például egy teljes felületén csiszolt, vagy díszített kerámia esetében nehéz, vagy lehetetlen a felületen formázásra utaló makronyomokat megfigyelni.

Másrészt a vizsgálatot a kerámiák töredezettsége is befolyásolhatja, mivel az apró töredékek gyakran nem alkalmasak makronyomok meghatározására, inkább a nagyobb, öszszefüggő edényfelületeken lehet ezeket megfigyelni.

Gyakran elöfordul az is, hogy nem lehet azonosítani a vizsgált edények összes formázási fázisát, ${ }^{62}$ például ismert a csőtalp, azonban a felső tálrész nem. Ennek ellenére rendkívül fontos minden információ dokumentálása, ${ }^{63}$ mivel ezeknek is jelentős szerepük van a leletanyag értelmezésében, mint az előbbi példa kapcsán a csőtalpak formázásának öszszehasonlítása.

Az edények formázási technológiájának vizsgálatát fontos kiegészíteni a kerámiák egyéb tulajdonságainak elemzésével, például a tipológia, stílus, nyersanyag vagy funkció kutatásával. ${ }^{64}$ Ezek ugyanis gyakran elengedhetetlenek a technológiai analízis során kapott eredmények megfelelö értelmezéséhez.

\footnotetext{
${ }^{58}$ Mivel a makronyomok vizsgálatának szerves részét képezi a törésfelületek megfigyelése, ideális az olyan leletanyag elemzése, melyben minél kevesebb a restaurátor által összeillesztett edény.

${ }^{59}$ Giligny 2010, 21; Gomart 2014b, 45.

${ }^{60}$ Smith-Crépeau 1983; Gelbert 2003, 15; Doosselaere 2010, 223; Giligny 2010, 21; Gomart 2014a, 146

${ }^{61}$ Roux 2010, 129, 137.

${ }^{62}$ Például a másodlagos formázási technikát.

${ }^{63}$ Roux 2010, 7.

${ }^{64}$ Roux 2010, 7
} 


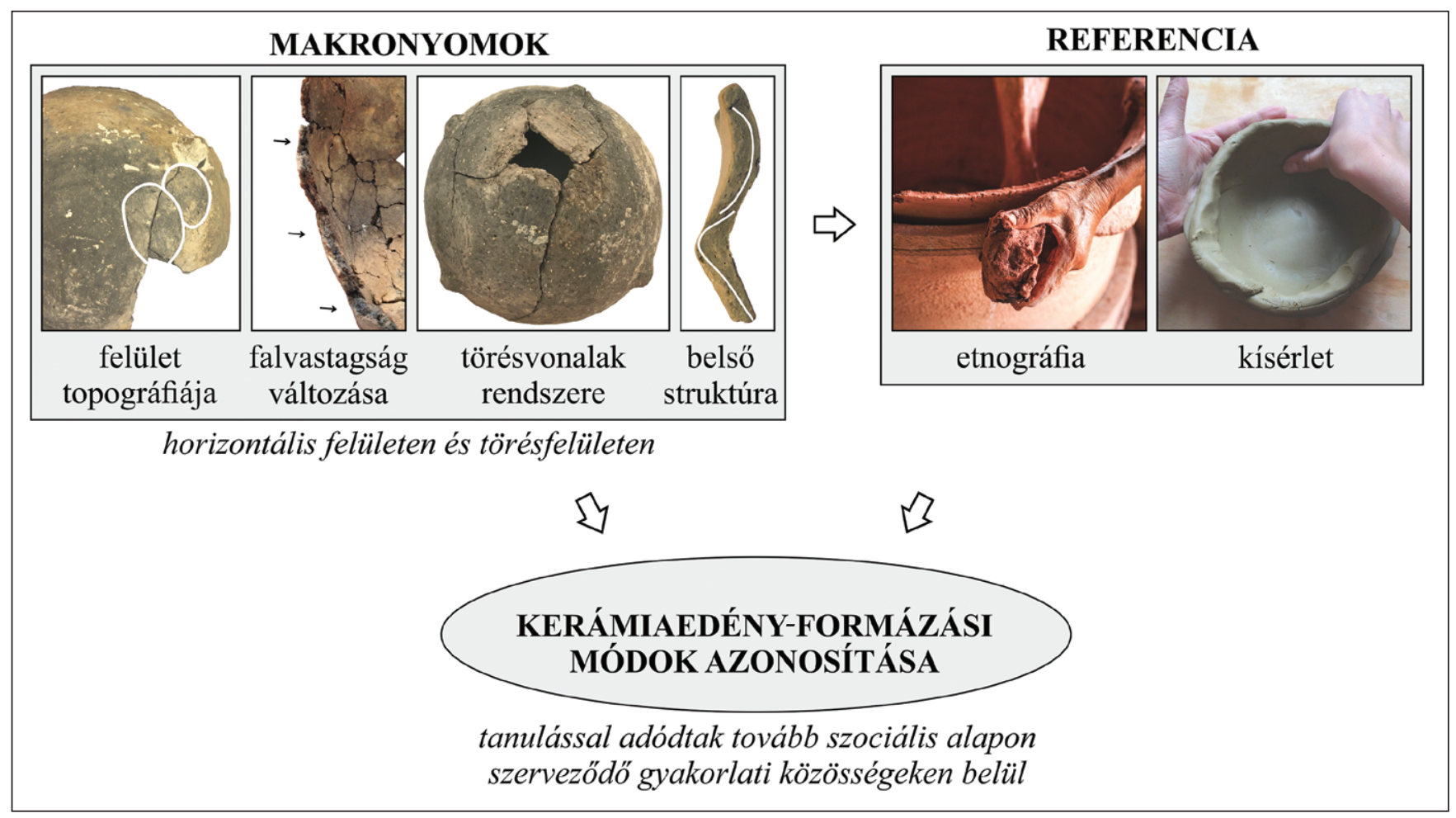

2. kép. A kerámiaformázás technológiai vizsgálatának folyamata

Fig. 2. The process of the technological analysis of ceramic fashioning

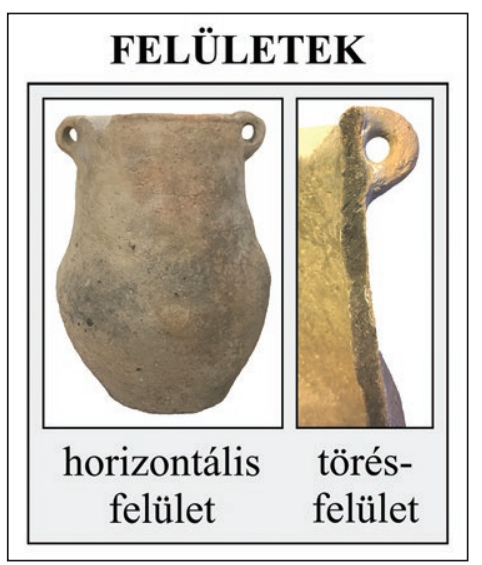

3. kép. Az edények két felülettípusa

Fig. 3. The two surface types of the potteries
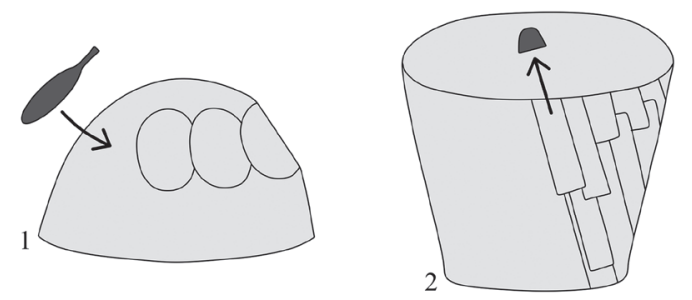

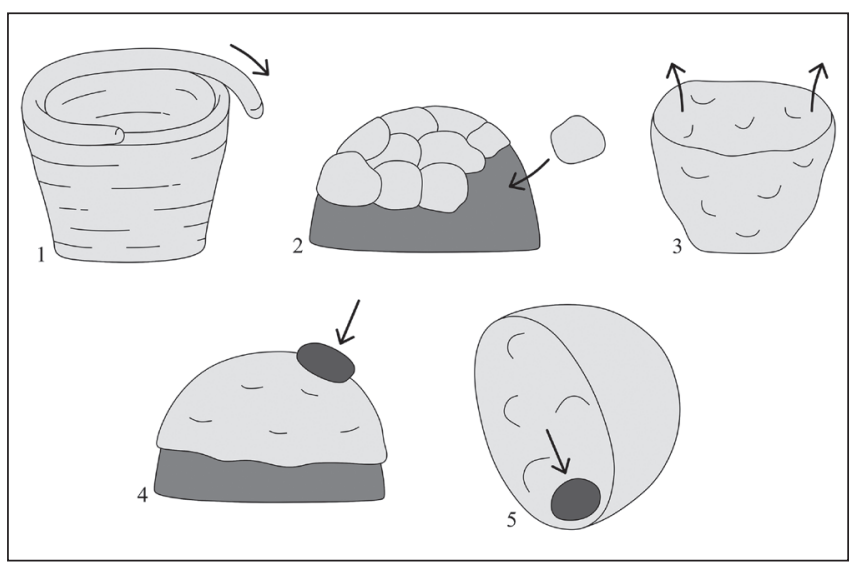

4. kép. A korongolatlan edények öt alapvető elsődleges formázási technikája. 1: hurkatechnika; 2: laptechnika; 3: modellálás; 4: formába nyomás; 5: kalapálás

Fig. 4. The five basic first fashioning techniques without a potter's wheel. 1 : coiling technique; 2 : slab technique; 3 : modeling; 4 : molding; 5 : hammering

5. kép. A korongolatlan edények két másodlagos formázási technikája. 1: ütéstechnika; 2: kaparás

Fig. 5. Two second fashioning techniques without a potter's wheel. 1: beating technique; 2 : scraping 


\section{ALAPVETŐ FORMÁZÁSI TECHNIKÁK A KORONGOLATLAN EDÉNYEK KÉSZÍTÉSÉNÉL}

A korongolatlan edények esetében az elsődleges és másodlagos formázási technikáknak több alaptípusa van, melyek jelenléte a neolitikum óta megfigyelhetô, és egyes régiókban napjainkban is használatban vannak. Az edényformázási metódus során a fazekasok számos fogást alkalmazhatnak a sikeres megvalósításhoz, a technikák alapvető jellemzői azonban változatlanok. Mivel a fazekasok az egyes formázási fázisoknál gyakran alkalmaznak különböző technikákat ${ }^{65}$ nagyon fontos az edény különbözö részeinek külön vizsgálata.

Az elsődleges formázási technikák öt alaptípusát különbözteti meg a szakirodalom (4. kép): 1) a hurkatechnikát (technique du colombin), 2) laptechnikát (technique des plaques), 3) modellálást (modelage), 4) formába nyomást (moulage) és 5) kalapálást (martelage). ${ }^{66}$ Ezzel szemben a másodlagos formázási technikák általános típusai kevésbé rögzültek. Valentine Roux hét másodlagos formázási technikát különít el etnográfiai megfigyelései alapján, ${ }^{67}$ ezek egy részét azonban a makronyomok vizsgálatával nehéz régészetileg azonosítani. Ezért jelen tanulmányban csak két olyan másodlagos formázási technikát tárgyalok, melyek karakterisztikus makronyomai lehetővé teszik a megbízható felismerését a kutatott anyagban: 1) az ütéstechnikát (battage) és a 2) kaparást (raclage) (5. kép). ${ }^{68}$

A különböző formázási technikák alapvető makronyomai univerzálisak, az edények korától és készítési helyétől függetlenül megegyeznek. Ezért a régészeti anyag vizsgálatakor fontos etnográfiai vagy kísérleti párhuzamokat keresni az azonosított formázási nyomokra, a felállított formázási hipotézis alátámasztására vagy cáfolására. ${ }^{69} \mathrm{Ez}$ nem jelenti automatikusan, hogy további kapcsolat lenne a vizsgált régészeti anyag és a párhuzamként hozott megfigyelések között, ez csupán az edényformázási módszer hasonlóságát hivatott jelezni. ${ }^{70}$

Példaként említve: ha egy Kárpát-medencei rézkori anyagban ugyanolyan makronyomokat sikerült dokumentálni, mint amilyeneket az etnológusok dokumentáltak egy kortárs afrikai közösségben, akkor joggal feltételezhetö, hogy a régészeti együttesben megfigyelt készítési nyomok ugyanolyan formázási folyamatnak a lenyomatai, mint az Afrikában megfigyeltek. Ugyanígy két régészeti korú kerámiaanyagban,

\footnotetext{
${ }^{65}$ Például más technikával formázzák meg a talpat és a testet.

${ }^{66}$ Rye 1981, 66-72; Pierret 2002, 20-23; Livingstone Smith 2007, 101; Doosselaere 2010, 233; Roux 2017, 124, Fig. 1, 42. ${ }^{67}$ Roux 2017, 91.

${ }^{68}$ Gomart 2014a, 147; Solnay in press.

${ }^{69}$ Gelbert 2003, 15; Doosselaere 2010, 223; Giligny 2010, 21 ; Gomart 2014a, 146.

${ }^{70} \mathrm{Az}$ etnográfiai párhuzamok referenciaként való alkalmazása mellett felmerülhet a magyarországi népi fazekassággal való párhuzam keresése, azonban a témában született kutatások főként korongolt edényekkel foglalkoznak, korongolatlan, kézzel formázott edényekkel kevésbé.
}

például egy franciaországi bronzkori és egy Kárpát-medencei rézkori lelőhelyen megfigyelt azonos makronyomok sem jelentenek azonnali párhuzamot a két együttes között, csupán rámutatnak a feltételezett formázási technikák hasonlóságára.

Ilyen, referenciaként alkalmazható, alapvető etnográfiai művek lehetnek például Alexandre Livingstone Smith kutatása Nyugat- és Közép-Afrikában, ${ }^{71}$ Olivier Gosselain vizsgálata Kamerunban, ${ }^{72}$ Barbara E. Frank, ${ }^{73}$ Eric Huysecom, ${ }^{74}$ Anne Mayor ${ }^{75}$ és Alain Gallay megfigyelései Maliban, ${ }^{76}$ Agnès Gelbert vizsgálata Szenegálban, ${ }^{77}$ Anne-Marie Pétrequin és Pierre Pétrequin kutatásai Namíbiában, ${ }^{78}$ Alex Gibson és Anne Woods vizsgálatai Új-Guineában, ${ }^{79}$ valamint Fabíola Andréa Silva megfigyelései Amazóniában. ${ }^{80}$

\section{Hurkatechnika}

Az egyik nagyon gyakori elsődleges formázási technika a hurkatechnika, ahol hosszúkás, kézzel formázott hurká(k)ból építik fel az edényt (4. kép 1). ${ }^{81}$

A hurkák összeillesztésének számos módja lehetséges, amelyeket Valentine Roux - föként etnográfiai példák alapján - három csoportba osztott, ${ }^{82}$ de a régészeti alkalmazás szempontjából bizonyos esetekben célravezetőbb csupán két kategóriát meghatározni. Az egyik a csípéssel (pincement) történő összeillesztés, amikor a szuperpozícióban egymásra kerülő hurkákat a két kéz vagy a hüvelykujj és a többi ujj közötti csípő mozdulattal rögzítenek egymáshoz. A nyomás hatására a hurka az ujjakkal párhuzamosan vékonyodik ugyan, de a többi összeillesztési módszerhez képest a hurkák itt deformálódnak a legkevésbé. A másik a szétnyomással (écrasement) vagy nyújtással (étirement) történő összeillesztés, ahol az új hurkát a korábbival szemben, ferdén, szaggatott mozdulatokkal nyomják a külső vagy a belső falra a mutatóujj külső felével. Eközben a tenyér a másik oldalon ellentart, így dolgozva össze a két hurkát. A hurkák ilyenkor nagyon erösen deformálódnak. ${ }^{83}$

A hurkák felépítésének többféle módja ismert. Egyrészt egyetlen hurkából, spirálisan feltekerve, mely leginkább a talpra, illetve a kisebb edényekre jellemző. Másrészt gyürüsen, ahol minden sort egyetlen, külön hurka alkot, amelyek két végét összedolgozzák, miután ráhelyezték az előző hurka-

\footnotetext{
${ }^{71}$ Livingstone SMith 2007.

${ }^{72}$ Gosselain 2002.

${ }^{73}$ FrANK 1993.

${ }^{74}$ HuYseCOM 1994.

${ }^{75}$ MAYOR 2010.

${ }^{76}$ Gallay 2012.

${ }^{77}$ Gelbert 2003.

${ }^{78}$ Pétrequin-PÉtrequin 1999.

${ }^{79}$ Gibson-Woods 1997.

${ }^{80}$ Silva 2008.

${ }^{81}$ Rye 1981, 68; Livingstone Smith 2007, 102; Roux 2017, 79.

${ }^{82}$ Roux 2017, 80.

${ }^{83}$ Gosselain 2002, 107-109; Martineau 2000, 133; Livingstone Smith 2007, 102; Roux 2017, 80.
} 
gyürüre. Harmadrészt szakaszosan, ahol sort alkotva az egyik hurkát helyezik a másik után egy korábbi, szintén több kisebb hurkából álló hurkagyürü felett. ${ }^{84}$

A hurkatechnikával készült edényeknek számos karakteres makronyoma van. ${ }^{85}$ A felület külső és belső topográfiáján gyakran hullámzás (ondulation) azonosítható, mely az edényfelületen, egymástól viszonylag egyenletes távolságra megfigyelhetö, hosszúkás bemélyedések - más néven bordák (ourlets) - sorozatát jelenti, melyet a hurkák nem megfelelő összedolgozása okoz (6. kép). ${ }^{86}$ A felületen gyakran megfigyelhetőek hosszirányú, illetve kör- és félkör alakú benyomódások (dépressions [sub-]circulaires), melyeket a paszta nyújtása, illetve a hurkák összedolgozása okoz. ${ }^{87}$ Két hurka összeillesztésekor, vagy bizonyos esetekben az edényfal lyukasztásakor előfordulhatnak kidudorodások (bourrelets) - vagyis felesleges pasztadarabok - is, melyeket gyakran az agyagpaszta túlzott nedvességtartalma vagy a felesleges agyag eltávolításának hiánya okoz (7. kép). ${ }^{88}$

A fal vastagságának változása lehet periodikusan ismétlődően elvékonyodó (diminution périodique répétitive), amenynyiben a hurkák nincsenek teljesen összedolgozva (8. kép). ${ }^{89}$ Ez az edényfal egészén, vagy bizonyos részein figyelhető meg, és a hurkák váltakozása okozza. ${ }^{90}$ A teljesen összedolgozott hurkáknál a fal egyenes.

A törésvonalak rendszere többnyire rendezetlen, azonban egyes repedésvonalak gyakran vízszintesek, esetleg lépcsőzetes alakúak, mivel ezek az edények a hurkák találkozásának mentén könnyebben törnek (9. kép). ${ }^{91}$

A hurkatechnikával készült edények belső struktúrája nagyon sokféle lehet attól függően, hogyan illesztették össze és dolgozták össze a hurkákat, és milyen másodlagos formázási technikát alkalmaztak. Csak néhány példát említek ezek közül. Megfigyelhető $\mathrm{O}$ és $\mathrm{C}$ alakú belső struktúra (10. kép), mely a talp esetében spirálisan összetekert, illetve a csípéssel összeillesztett hurkákra jellemző. ${ }^{92}$ Lehet kifelé (11. kép) vagy befelé ferde szögü (12. kép), valamint $\mathrm{S}-\mathrm{Z}$ alakú belső szerkezetü is (13. kép), melyet minden esetben a hurkák különböző mértékű és irányú deformálódása okoz. ${ }^{93}$

${ }^{84}$ Roux 2017, 82.

${ }^{85} \mathrm{~A}$ cikkben a bemutatott formázási technikák legjellegzetesebb makronyomait sorolom fel. Ez azonban nem jelenti azt, hogy minden edényen azonosítani lehet minden adott formázásra jellemző diagnosztikus jegyet. Bizonyos kerámiákon több, másokon kevesebb makronyom azonosítható (lásd feljebb).

${ }^{86}$ Doosselaere 2010, 224, Tab. 16; Gomart 2014b, 65; Roux 2017, 200.

${ }^{87}$ Doosselaere 2010, 224, Tab. 16; Gomart 2014b, 61.

${ }^{88}$ Doosselaere 2010, 252; Livingstone Smith 2007, 131.

${ }^{89}$ Nagyjából ennek a kifejezésnek feleltethető meg az alkalmankénti vastagságváltozás (variations dépaisseur ponctuelles) kifejezés is. Livingstone Smith 2007, 119; Doosselaere 2010, 195.

${ }^{90}$ Doosselaere 2010, 269, Tab. 17; Roux 2017, 200.

${ }^{91}$ Rye 1981, 68, Fig. 49, c; Doosselaere 2010, 224, Tab. 16; Roux 2017, 200.

${ }^{92}$ Bosquet et al. 2005, 110; Livingstone Smith 2007, 121; GoMart 2014b, 65.

${ }^{93}$ Martineau 2000, 158-159; BosQuet et al. 2005, 110; LivingStone Smith 2007, 121; Gomart 2014a 280, Tab. 81; Roux 2017; 203-205.
A hurkatechnikát az etnográfiai kutatások ${ }^{94}$ és kísérleti megfigyelések ${ }^{95}$ mellett számos régészeti anyagban is sikerült azonosítani, például a neolitikus Vonaldíszes kultúra nyugat-európai és Kárpát-medencei településein, ${ }^{96}$ az alföldi késő neolitikumban, ${ }^{97}$ valamint a hazai rézkori BalatonLasinja-, Boleráz- és Baden-kultúrák és a bronzkori Nyírség-kultúra Szaniszló-csoportjának leletanyagában. ${ }^{98}$ Továbbá megfigyelhető volt Franciaországban a Jura megyei tókörnyéki neolitikus, ${ }^{99}$ illetve közép-nyugat-franciaországi bronzkori lelöhelyeken is. ${ }^{100}$

A hurkatechnika hazai megfigyeléséhez fontos hozzáfüzni, hogy Gucsi László és Füzesi András kettéválasztják a hurka- és szalagtechnikát az egyes elemek törésfelületen látható szélessége alapján, ahol a hurkák átlagos szélességét $1-3 \mathrm{~cm}$, a szalagokét átlagosan 5-6 cm között írják le. ${ }^{101}$ Jelen megközelítés bemutatásakor azonban nem tartottam szükségesnek a kettéválasztásukat, mivel a kerámiák formázási technológiáját vizsgáló módszertani iskola az agyag átalakításának azonos fizikai módját azonos technikának tekinti, ${ }^{102}$ így az elemek eltérő mérete ebből a megközelítésből nem tekinthető technikai különbözőségnek.

\section{Laptechnika}

Szintén gyakori elsődleges formázási technika a laptechnika, ahol előre elkészített elemekből, lapokból rakják össze az edényt egy forma segítségével (4. kép 2). A lapok formája és elkészítési módja sokféle lehet. ${ }^{103}$

A lapokat egy formára helyezik rá, először az első lapot, majd az előzőt részben átfedve a következőket, a külső vagy belső oldalra attól függően, hogy domború vagy homorú formáról van szó (14. kép). A lapokat folyamatos ütéssel, leginkább egy ütő vagy kéz, esetleg láb segítségével dolgozhatják össze. ${ }^{104}$

A laptechnikával készült edények makronyomai gyakran nagyon karakteresek. Az edények felületének topográfiájában esetenként finom egyenetlenség tapasztalható, a felület ugyanis bemélyedhet a lapok összeillesztésénél. ${ }^{105}$

${ }^{94}$ Gosselain 2002, 101-112; Livingstone Smith 2007, 102-104; SiLVA 2008, 226; Gallay 2012, 297-306.

${ }^{95}$ Martineau 2000; Giligny 2015.

${ }^{96}$ Bosquet et al. 2005; Gomart 2014a; Gomart 2014b, 280, Tab. 81; GILIGNY 2015, 75-78.

${ }^{97}$ FÜZESI 2019, 91-92.

${ }^{98}$ GuCsi 2000, 90-93; GuCsi 2006; GUCSI 2009, 450-452.

${ }^{99}$ Martineau 2000.

${ }^{100}$ Manem 2008, 28; Manem 2010, 32-34.

${ }^{101}$ GuCsi 2000; GuCsi 2006.

${ }^{102}$ Roux 2017, 63.

${ }^{103}$ Rye 1981, 71-72; VANDiver 1987, 13, Pl. 2; 24, Pl. 8; Roux 2017, 84.

${ }^{104}$ VANDIVER 1987; Roux 2017, 84-86.

${ }^{105}$ Dooosselaere 2010, 224, Tab. 16. 


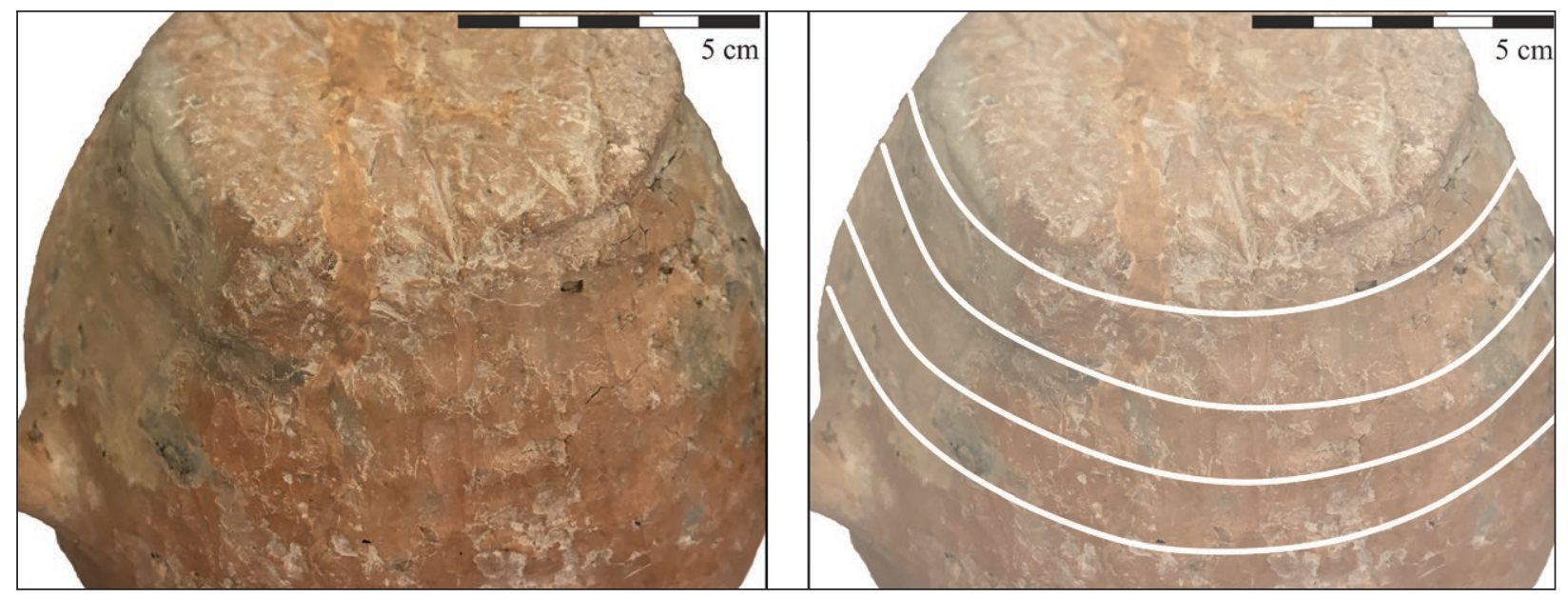

6. kép. Bordázat az edény horizontális felületén (Tiszagyenda-Vágott-halom)

Fig. 6. The undulation on the horizontal surface (Tiszagyenda-Vágott-halom)

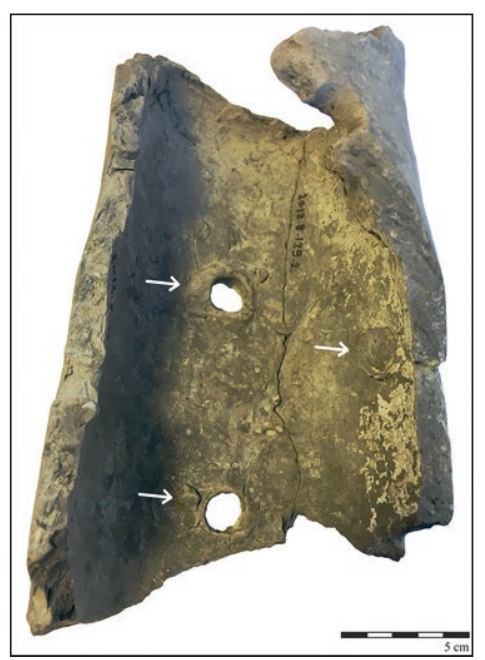

7. kép. Kidudorodások a csőtalp átfúrásánál az edény horizontális felületén (Tiszagyenda-Vágott-halom)

Fig. 7. Bulges of the hollow-pedestal on the horizontal surface (Tiszagyenda-Vágott-halom)

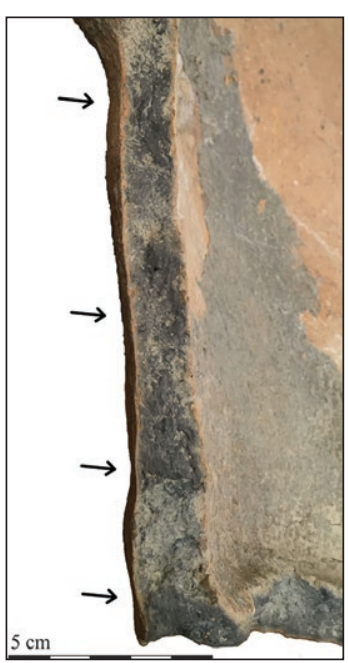

8. kép. A falvastagság periodikusan ismétlődő elvékonyodása (Tiszagyenda-Vágott-halom)

Fig. 8. Periodic decrease of the of wall thickness (Tiszagyenda-Vágotthalom)

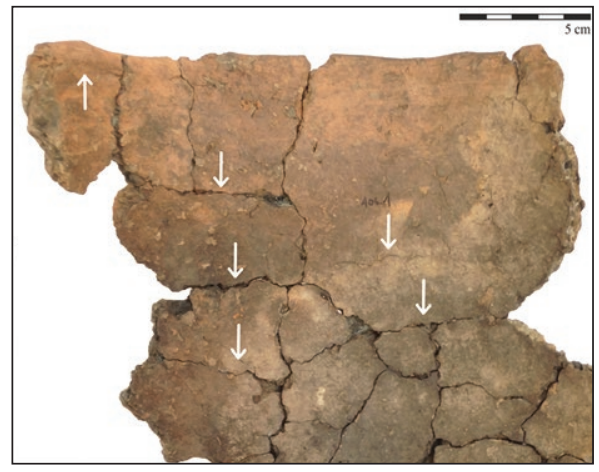

9. kép. Vízszintes irányú törésvonalak (Polgár-Király-ér-part)

Fig. 9. Horizontal fractures (Polgár-Király-ér-part)

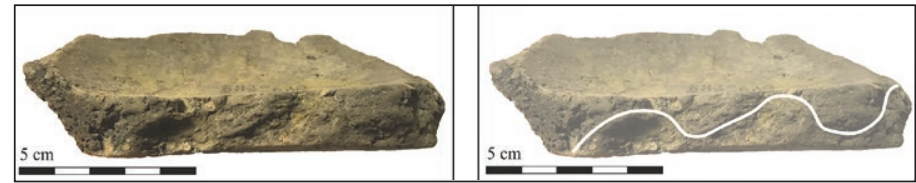

10. kép. 0 és $C$ alakú belső struktúra a törésfelületen (Polgár-Király-ér-part) Fig. 10. 0- and C-shaped internal structure in cross-section (Polgár-Király-érpart) 


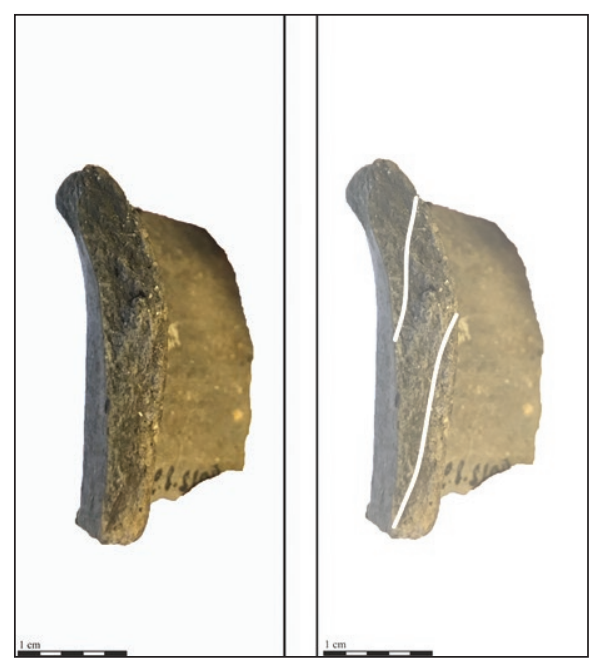

11. kép. Kifelé ferdeszögú belső struktúra a törésfelületen (TiszagyendaVágott-halom)

Fig. 11. Internal structure inclined outwards in cross-section (Tiszagyenda-Vágott-halom)

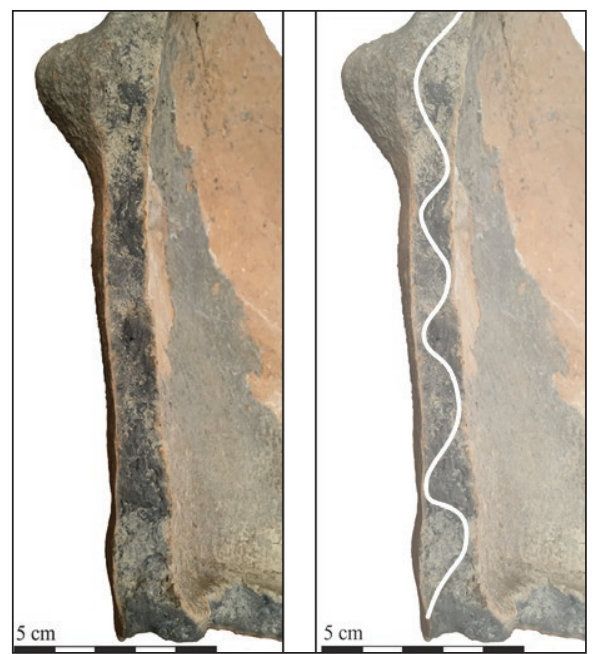

13. kép. S-Z alakú belső struktúra a törésfelületen (Tiszagyenda-Vágotthalom)

Fig. 13. S-Z-shaped internal structure in cross-section (TiszagyendaVágott-halom)

15. kép. A rosszul megerősített lapok találkozásainak szétválása, illetve a lapok tovább törése (Tiszagyenda-Vágott-halom)

Fig. 15. The separation of the poorly reinforced slabs and the further fracturing of the slabs (Tiszagyenda-Vágott-halom)

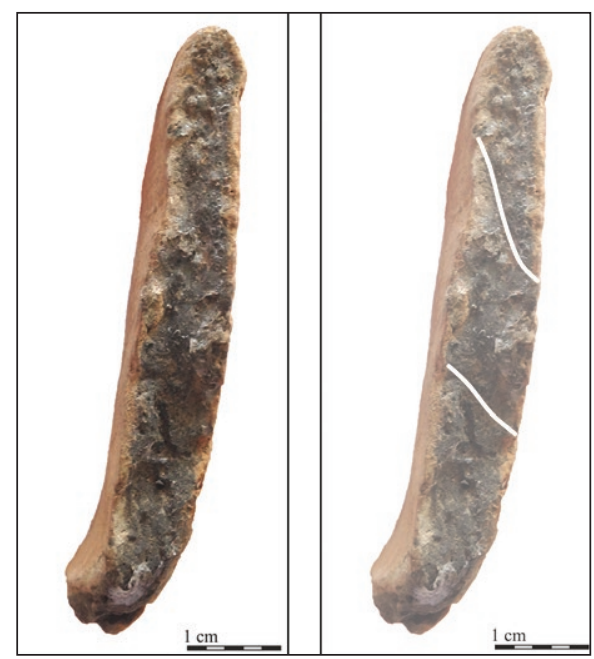

12. kép. Befelé ferdeszögű belső struktúra a törésfelületen (Tiszagyenda-Vágott-halom)

Fig. 12. Internal structure inclined inwards in cross-section (Tiszagyenda-Vágott-halom)

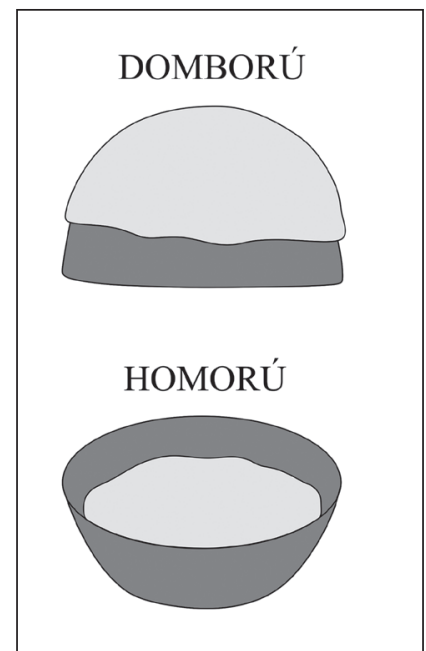

14. kép. Homorú és domború forma

Fig. 14. Concave and convex mold

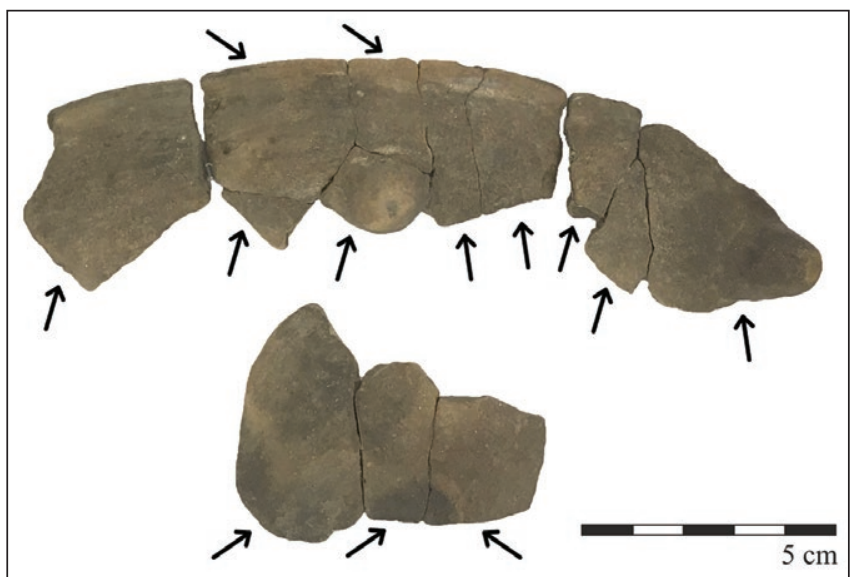


A laptechnikával készült kerámiáknál eltérő lehet a fal vastagsága a felület elegyengetésétől függően. ${ }^{106} \mathrm{~A}$ törésvonalak rendszere többnyire rendezetlen. A rosszul megerösített lapok találkozásai gyakran kettéválnak, megrepednek (15. kép). A megerősített, jól összedolgozott lapok esetében gyakori a réteges törésvonal és repedés. ${ }^{107} \mathrm{~A}$ belső struktúra lehet a fallal párhuzamos, valamint különböző irányítások figyelhetőek meg a két lap találkozásánál aszerint, hogyan illeszkedtek össze (16. kép). ${ }^{108}$

A laptechnika jól ismert az etnoarcheológiai szakirodalomban, a Közel-Keleten például hosszú időn keresztül folyamatosan alkalmazták. ${ }^{109}$

\section{Modellálás}

A legalapvetőbbnek tekinthető elsődleges formázási technika a modellálás, ${ }^{110}$ amely az agyagpaszta különféle benyomásokkal való formázását jelenti (4. kép 3). ${ }^{111} \mathrm{~A}$ modellálást Valentine Roux szerint kétféle módon lehet végrehajtani. Egyrészt csípéssel (pincement), amely során a hüvelykujj és a többi ujj között lévő agyagpaszta sorozatos, tagolt benyomások következtében formálódik. Másrészt benyomkodással, majd nyújtással (creusement-étirement), amikor a pasztát határozott benyomkodások után a két kéz között folyamatosan nyújtják, megformázva ezzel az edény falát. A külső oldalon a kéz általában támasztékként szolgál, míg a belső oldalon a másik kéz ujjai tagolt mozdulatokkal, függőleges irányba húzzák az agyagpasztát. ${ }^{112}$ Mindkét módszer célja, hogy a fal a folyamatos nyomás és/vagy nyújtás hatására elvékonyodjon. ${ }^{113}$

A modellálásnak kevés a karakterisztikus makronyoma. Az edények külső és belső felületének topográfiája gyakran egyenetlen, kör vagy félkör alakú (dépressions [sub-]circulaires) (17. kép), illetve hosszúkás benyomódásokkal (dépressions oblongues) (18. kép), melyek a formázás közbeni ujj-

\footnotetext{
${ }^{106}$ Rye 1981, 72; Doosselaere 2010, 224, Tab. 16.

${ }^{107}$ Doosselaere 2010, 224, Tab. 16; Roux 2017, 207.

${ }^{108}$ VAndiver 1987, 15, Fig. 6; Roux 2017, 84-86.

${ }^{109}$ VANDiver 1987.

${ }^{110}$ Füzesi András ezt „egy tömbből való formázásnak” nevezi. FÜZESI 2019, 91. Azonban talán szerencsésebb egy olyan fordítás bevezetése, mely nem keverhetö össze más technikákkal. Ugyanis mind a későbbiekben részletesen tárgyalt formába nyomás, mind a kalapálás technikája során egy agyagdarabból formázzák az edényt, nem elemekből, ahogyan a hurka- vagy laptechnikánál.

${ }^{111}$ Gosselain 2002, 86; Livingstone Smith 2007, 101.

${ }^{112}$ Rye 1981, 81; Gosselain 2002, 86, 93; Livingstone Smith 2007, 102, 105; Roux 2017, 87.

${ }^{113}$ Néhány esetben csak a becsípéssel formázást nevezik modellálásnak. Livingstone SMith 2007, 101-102. Én azért nevezem egységesen modellálásnak mindkét formázási módszert, mert a régészeti anyagban a makronyomok alapján sokszor nehéz elkülöníteni őket, szemben az etnográfiai tanulmányokkal, ahol pontosan megfigyelhetők és leírhatók a fazekasok gesztusai.
}

benyomódást, illetve nyújtást jelzik. A technikának ez a legkarakterisztikusabb makronyoma, amely alapján a leggyakrabban azonosítják. ${ }^{114}$

A benyomódásoknál a fal néhány esetben elvékonyodik, a talp pedig félholdszerüen megvastagodik, melyet az agyaggolyóból való becsípéssel vagy benyomkodással és nyújtással történő formázás okoz (19. kép). ${ }^{115}$

A modellált edények törésvonalának nincsen határozott rendszere, ${ }^{116}$ sem a belső struktúrának nincsenek egyértelmüen a formázásra utaló jegyei, a belső szerkezet gyakran a fallal párhuzamos. ${ }^{117}$

A modellálás több etnográfiai tanulmány mellett ${ }^{118}$ néhány régészeti anyagból is ismert, például közép-nyugat-franciaországi bronzkori lelőhelyekről, ${ }^{119}$ vagy a Kárpát-medencei késő neolitikumból. ${ }^{120}$

\section{Formába nyomás}

A formába nyomás az agyagpaszta erőteljes nyomásával együtt járó formázási technika (4. kép 4), ${ }^{121}$ ahol egy domború vagy homorú forma segítségével alakítják ki az edény formáját (14. kép). ${ }^{122}$

A formázás során az agyagpasztát folyamatos vagy szaggatott, finomabb ütésekkel nyomják rá a formára, amíg az át nem veszi a forma alakját, illetve ezzel együtt a rajta lévő esetleges mintázatot, lenyomatot. A forma sokféle anyagból készülhet, például száraz vagy égetett agyagból, ${ }^{123}$ melyre különféle tapadásgátló anyagot is tehetnek, hogy ne ragadjon oda a rányomott paszta. ${ }^{124}$

A formába nyomásnak meghatározható néhány jellemző makroméretü nyoma. A felület topográfiáján az öntőformával érintkező falon gyakran megtalálhatók annak negatív lenyomatai. Az ellenkező edényfalon pedig - esetenként - az ütő nyomai láthatóak. ${ }^{125}$

${ }^{114}$ Rye 1981, 70, 72; Livingstone Smith 2007, 130; Doosselaere 2010, 269, Tab. 17; Roux 2017, 208.

${ }^{115}$ Doosselaere 2010, 224, Tab. 16; Roux 2017, 208.

${ }^{116}$ Rye 1981, 70, 72; Livingstone Smith 2007, 130; Doosselaere 2010, 269, Tab. 17; Roux 2017, 208.

${ }^{117}$ Rye 1981, 70, 72; Roux 2017, 208-210.

${ }^{118}$ Frank 1993, 388; Gosselain 2002, 93-100; Livingstone SMith 2007, 101-102; MAYOR 2010, 11, Fig. 2.

${ }^{119}$ Manem 2010, 33.

${ }^{120}$ FÜZESI 2019, 91.

${ }^{121}$ Füzesi András a kifejezést mintázásnak fordítja. FüZESI 2019, 91. Azonban talán szerencsésebb lenne egy technikai megvalósításra jobban utaló kifejezés, mivel a forma (a minta) sokszor csupán egy megvalósítást segítő eszköz, nem egy utánozni kívánt végeredmény.

${ }^{122}$ Livingstone Smith 2007, 106; Roux 2017, 88.

${ }^{123}$ Gosselain 2002, 69; Roux 2017, 88.

${ }^{124}$ Manem 2008, 45; Roux 2017, 88.

${ }^{125}$ Rye 1981, 81; Huysecom 1994, 39; Livingstone Smith 2007, 138; Manem 2008, 45; Doosselaere 2010, 269, Tab. 17; Roux 2017, 210. 


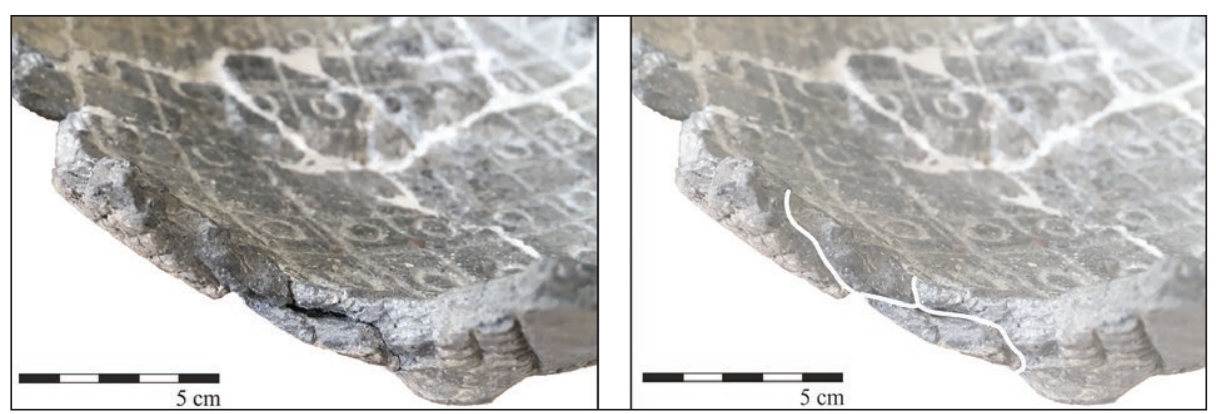

16. kép. A lapok találkozásának nyoma a törésfelületen (Tiszagyenda-Vágott-halom)

Fig. 16. The trace of encountered slabs in cross-section (Tiszagyenda-Vágott-halom)

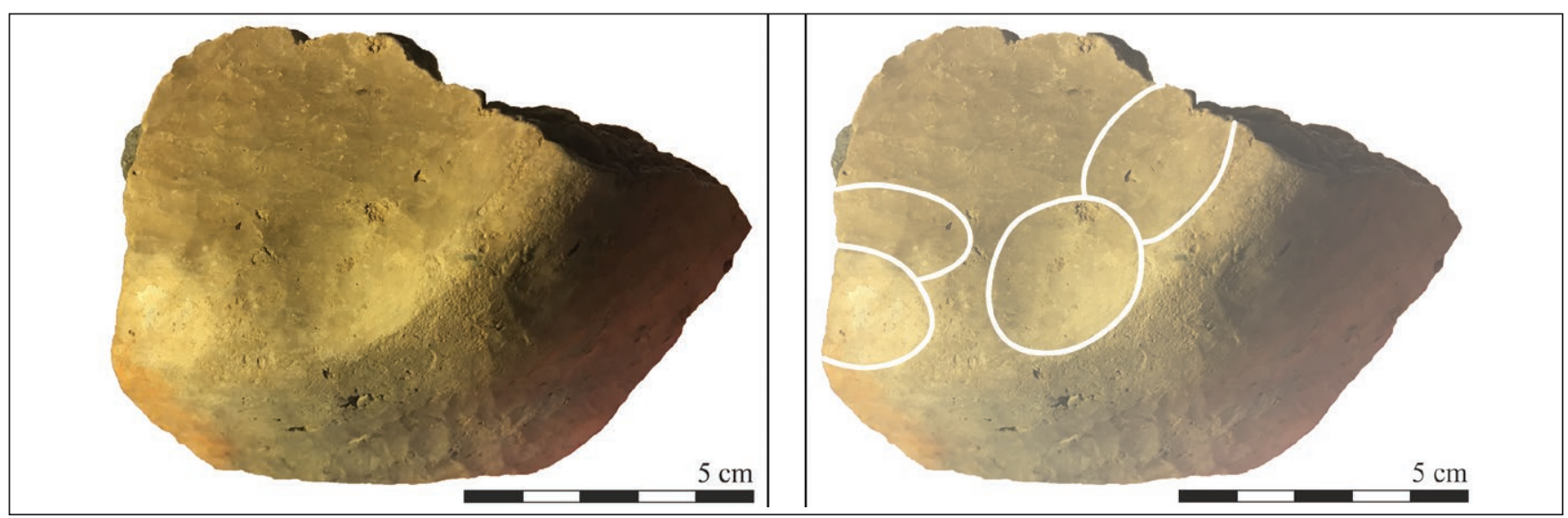

17. kép. Kör és félkör alakú benyomódások az edény horizontális felületén (Tiszagyenda-Vágott-halom)

Fig. 17. Circular and semicircular depressions on the horizontal surface (Tiszagyenda-Vágott-halom)

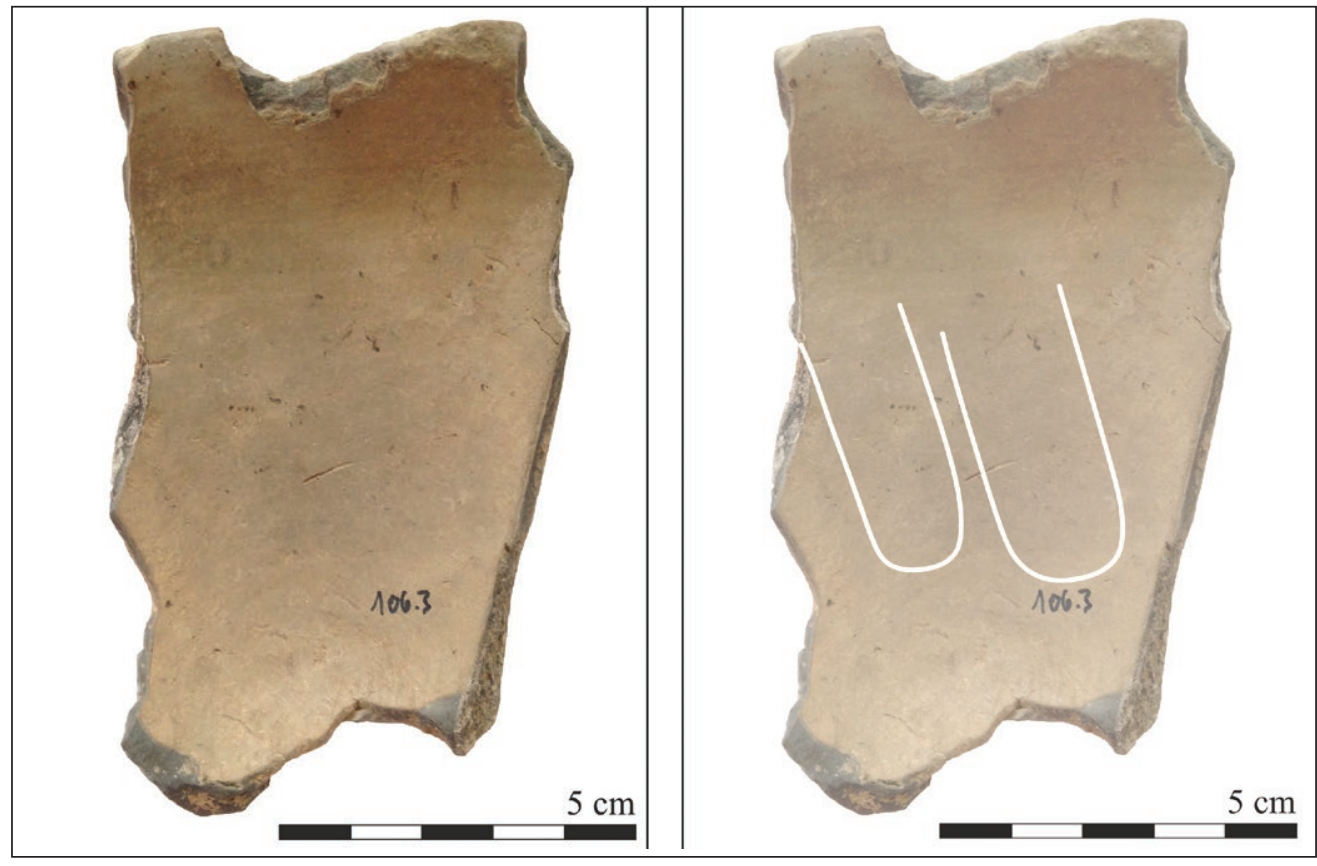

18. kép. Hosszúkás benyomódások az edény horizontális felületén (Polgár-Király-ér-part)

Fig. 18. Longitudinal depressions on the horizontal surface (Polgár-Király-ér-part) 


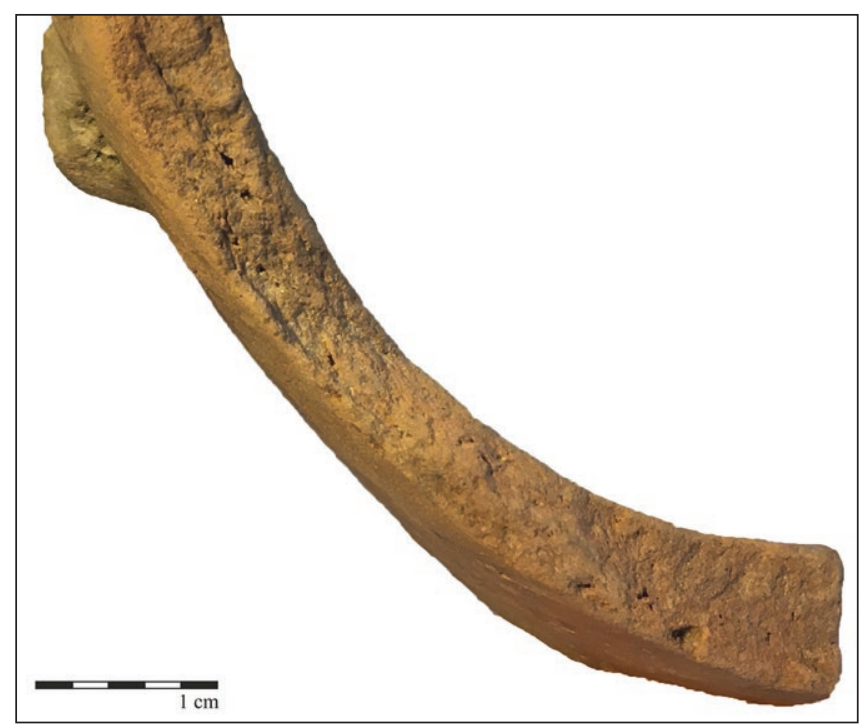

19. kép. A talp félholdszerü megvastagodása (Tiszagyenda-Vágotthalom)

Fig. 19. Crescent-like thickening of the base (Tiszagyenda-Vágott-halom)

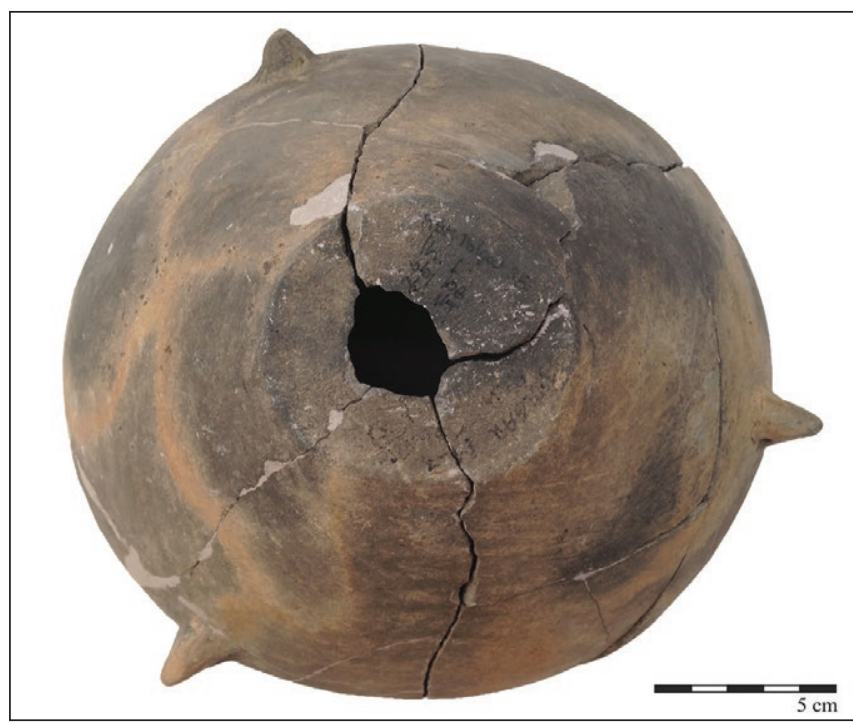

20. kép. Sugár irányú törésvonalak a peremtôl a talp felé (Polgár-Királyér-part)

Fig. 20. Radial fractures from the rim in the direction of the base (PolgárKirály-ér-part)

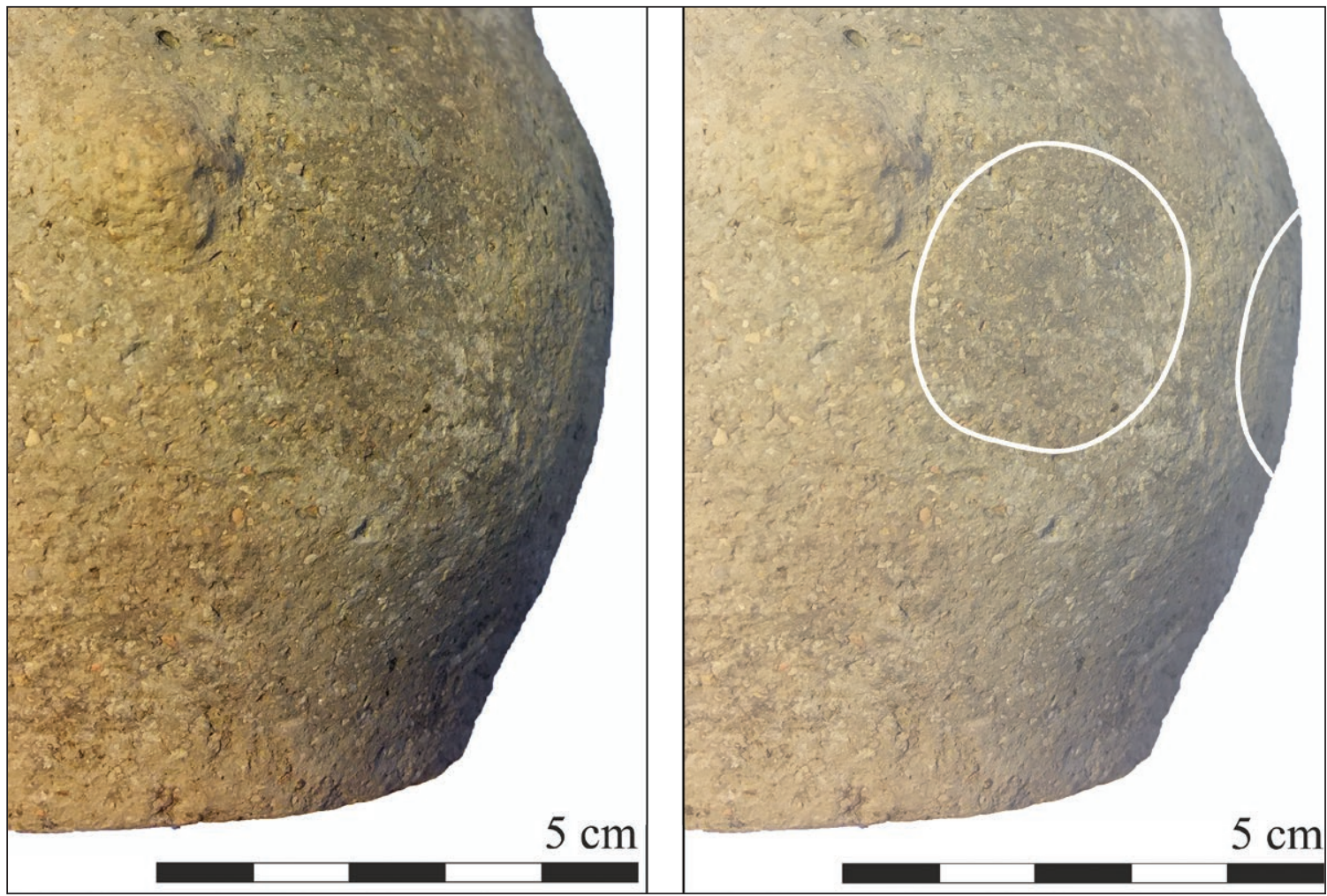

21. kép. Fazetták az edény horizontális felületén (Tiszagyenda-Vágott-halom)

Fig. 21. Facets on the horizontal surface (Tiszagyenda-Vágott-halom) 
A fal elvékonyodhat az ütő okozta benyomódásoknál, ${ }^{126}$ de a falvastagság gyakran egyenletes. ${ }^{127}$

A törésvonalak rendszere bizonyos esetekben karakterisztikus lehet. A formába nyomással készült edények sok esetben sugár irányban törnek a peremtől a talp felé (20. kép). ${ }^{128}$

A belső struktúra nehezen meghatározható, néhol a fallal párhuzamos. $^{129}$

A formába nyomás technikájának számos etnográfiai párhuzama ismert, ${ }^{130}$ továbbá régészeti korú kerámiaegyüttesben is sikerült megfigyelni, például a bronzkori Közép-NyugatFranciaországban. ${ }^{131}$

\section{Kalapálás}

A kalapálás egy olyan, a régészeti anyagban ritkán megfigyelt elsődleges formázási technika, melynek terminológiája sokszor nem teljesen egységes. ${ }^{132} \mathrm{Az}$ alapvető leíró kritériumot talán úgy lehetne meghatározni, hogy a kalapálás a nedves agyagpaszta ütéssel való formázása, melyet ez az erőteljes mozdulat különböztet meg a formába nyomás technikájától. ${ }^{133}$

Ezen kritériumon kívül egyes szerzők az etnográfiai példák alapján úgy választják el ezt a technikát a formába nyomástól, hogy a kalapálást öntőforma használata nélküli technikaként írják le. ${ }^{134}$ Ebben az esetben a pasztát egy támasztékra vagy a földre helyezik, esetleg a passzív kéz tenyerében tartják (4. kép 5). Más kutatók viszont a forma felületére mért ütés erőssége, illetve a paszta mozgathatósága alapján tesznek különbséget a két technika között, így ennek régészeti azonosítása igen problematikus. ${ }^{135}$

A formázás az agyagpaszta közepétöl kifelé (divergent) vagy a külső részétől befelé (convergent) tartó, ököllel vagy egy eszközzel való erőteljes ütögetéssel, más néven kalapálással történik. Mindkét esetben az edényt ívben ütögetik, s ütés közben addig forgatják, amíg a falvastagság nagyjából egyenlő nem lesz a kerámia teljes felületén. ${ }^{136}$

\footnotetext{
${ }^{126}$ Doosselaere 2010, 269, Tab. 17.

${ }^{127}$ Rye 1981, 81; Roux 2017, 210.

${ }^{128}$ Doosselaere 2010, 269, Tab. 17; Manem 2008, 44.

${ }^{129}$ Roux 2017, 212.

${ }^{130}$ Huysecom 1994, 39; Gallay 2002, 54; Gosselain 2002, 80; Gelbert 2003, 44; Livingstone Smith 2007, 50, Fig. V-13a; MAYOR 2010, 11, Fig. 2.

${ }^{131}$ Manem 2010, 33.

${ }^{132}$ Bizonyos szerzők döngölésnek (pillonage) nevezhetik. HuyseСОМ 1994, 32.

${ }^{133}$ Doosselaere 2010, 228; Roux 2017, 86, Fig. 1, 19.

${ }^{134}$ Livingstone Smith 2007, 108; Gallay 2012, 173-177; Roux 2017, 87.

${ }^{135}$ Gosselain 2002, 91; Doosselaere 2010, 228-233.

${ }^{136}$ Livingstone Smith 2007, 108; Gosselain 2010, 673; Roux $2017,87$.
}

Nehéz meghatározni a kalapálás jellegzetes makronyomait, melyek erősen függenek a formázási technika definíciójától. Amennyiben a formán készült, erőteljes ütésekkel formázott edényeket soroljuk ide, a nyomok hasonlóak, mint a formába nyomásnál. Ha azonban a forma nélkül készült, ütéssel kialakított edények készítési technikáját nevezzük így, az edény formája gyakran szabálytalan lesz, melynek gyakran ferde a talpa. ${ }^{137}$

A kalapálást számos etnográfiai kutatás során sikerült rögzíteni, ${ }^{138}$ régészeti anyagban azonban az említett okból még nem mutatták ki.

\section{Ütéstechnika}

Az ütéstechnika egy jellegzetes másodlagos edényformázási technika, amely a még nedves vagy már száradásban lévő edény felületének ütését jelenti, ${ }^{139}$ mely során az edény falát nemcsak profilálhatják, hanem erősen át is alakíthatják. A formázás során az aktív kézben lévő ütővel ütik az edény egyik falát, míg ugyanennek az edényfalnak a túlsó felülete a passzív kézben (többnyire a tenyéren) vagy egy ellentámasztékon fekszik (5. kép 1). ${ }^{140}$

$\mathrm{Az}$ ütéstechnika egyik legjellegzetesebb makronyoma, hogy az egyik felület topográfiáján fazetták (facettes) láthatóak, ${ }^{141}$ vagyis egyenes felszínü, félkör, kör, ovális vagy - egymás fedésében - sokszög alakú nyomok az edényfalon, melyek a formázáshoz használt ütő nyomai (21. kép). ${ }^{142}$ A másik felületen egymást fedő, vagy kis távolságban lévő benyomódások, melyek az ellentámaszték jelei. ${ }^{143}$

A fazetták mentén a fal többnyire kiegyenesedik és elvékonyodik (22. kép). ${ }^{144}$

A belső szerkezet a fallal párhuzamos, lemezes az összenyomás következtében. ${ }^{145}$

${ }^{137}$ Livingstone Smith 2007, 140-140; Doosselaere 2010, 269, Tab. 17; Roux 2017, 212-213.

${ }^{138}$ Huysecom 1994, 32-35; Gosselain 2002, 91-93; Livingstone SMith 2007, 108-110.

${ }^{139}$ Füzesi András ütögetésnek fordítja. Füzesi 2019, 91. Azonban szerettem volna a francia technique de battage, illetve az angol beating technique kifejezések pontos fordítását használni, ezzel is elkerülve az ütögetés mint mozdulat és a formázási technika közötti keveredést.

${ }^{140}$ Rye 1981, 84; Martineau 2000, 138; Doosselaere 2010, 263; Roux 2017, 96.

${ }^{141}$ A szakirodalomban a fazetták kifejezés mellett (DoosselaERE 2010, 186.) nevezhetik őket lapos zónáknak (zones plates) (Livingstone SMith-Visseyrias 2010, 127.) vagy lapocskáknak (aplats) is (Gomart 2014, 140). A lapocskák fogalma jelen tanulmányban más makronyomot takar (lásd a kaparásnál).

${ }^{142}$ Rye 1981, 85; Martineau 2000, 139; Doosselaere 2010, 269, Tab. 17; GoMART 2014, 77; Roux 2017, 217.

${ }^{143}$ Roux 2017, 217

${ }^{144}$ Martineau 2000, 139; Doosselaere 2010, 269, Tab. 17; Gomart 2014, 77; Roux 2017, 217.

${ }^{145}$ GOMART 2014b, 77. 
Az ütéstechnikát a különböző etnográfiai megfigyelések mellett ${ }^{146}$ régészeti kutatások során is sikerült dokumentálni, például a neolitikus Vonaldíszes-kultúra nyugat-európai ${ }^{147}$ és Kárpát-medencei, ${ }^{148}$ a franciaországi Jura megyei tókörnyéki neolitikus lelőhelyeken, ${ }^{149}$ valamint Közép-Nyugat-Franciaországban a bronzkorban. ${ }^{150}$

\section{Kaparás}

A kaparást egyaránt sorolhatják a másodlagos formázási technikákhoz ${ }^{151}$ és a felületkezeléshez is. ${ }^{152}$ A saját anyagvizsgálataim alapján úgy határoznám meg a különbséget, hogy a másodlagos formázáskor a kaparás a végső forma kialakításában játszik szerepet, míg a felületkezeléskor csak az edény felszínének módosítására szolgál.

A kaparásnak a másodlagos formázási technikaként való alkalmazása során a még nedves edény külső vagy belső falát egy durva felületű tárggyal (csonttal, kagylóval, kőpengével, kerámiatöredékkel) kaparják, így hozva létre az edény végső profilját (5. kép 2). A kaparás iránya kerámiánként eltérő lehet, de egy edényen mindig azonos irányú. ${ }^{153}$

A kaparás makroszkopikus nyomai kizárólag a felület topográfiájában azonosíthatóak. A kapart külső vagy belső felületen lapocskák (aplats) figyelhetőek meg, ${ }^{154}$ vagyis ovális, négyszög vagy lekerekített négyszög alakú nyomok, melynek felülete eszköztől függően lehet egyenes, sima, illetve durva, apró agyagcsomókkal és csíkokkal (23. kép). ${ }^{155}$

Ezt a másodlagos formázási technikát az etnográfiai megfigyelések részletesen leírják, ${ }^{156}$ a régészeti azonosításkor azonban eddig többnyire a felületkezelési technikák között jelent meg. ${ }^{157}$

\section{FORMÁZÁSI TRADÍCIÓK ÉS GYAKORLATI KÖZÖSSÉGEK AZONOSÍTÁSA}

A formázási technikák azonosításával rekonstruálni lehet az edények formázási müveleteinek rendezett sorrendjét, vagyis metódusát. ${ }^{158}$ Ezek hosszú ideig továbbadódhatnak fazekas-

\footnotetext{
${ }^{146}$ Gibson-Woods 1997, 217; PÉtrequiN-PÉtrequin 1999, 75.

${ }^{147}$ Gomart 2014b, 280, Tab. 81.

${ }^{148}$ GOMART 2014a, 147.

${ }^{149}$ Martineau 2000, 138.

${ }^{150}$ MANEM 2010, 33.

${ }^{151}$ Rye 1981, 86; Gosselain 2002, 113; Gallay 2012, 316; Roux 2017, 92;

${ }^{152}$ Manem 2010, 33; Gallay 2012, 328-329; Gomart 2014b, 80.

${ }^{153}$ Rye 1981, 86; Gosselain 2002, 113-120; Gallay 2012, 63; GoMART 2014, 80; Roux 2017, 92.

${ }^{154}$ A szakirodalomban nevezhetik őket négyszög alakú benyomódásoknak (dépressions rectilignes) is: DoosselaERE 2010, 187.

${ }^{155}$ Rye 1981, 81; Doosselaere 2010, 280-281; Roux 2017, 216.

${ }^{156}$ Gosselain 2002, 115-117; Gallay 2012, 328-329.

${ }^{157}$ MANEM 2010, 33; Gomart 2014b, 80.

${ }^{158}$ Roux 2017, 63.
}

ról fazekasra anélkül, hogy a technikák alapvető jellemzői megváltoznának, köszönhetően a tanulási folyamat során rögzült, és később már nehezen változtatható kognitív és motorikus készségeknek. ${ }^{159}$ Mivel ez a tudásátvételi folyamat mindig a szociális alapon szerveződő gyakorlati közösségeken belül zajlik, a különböző metódusok jelenléte szociális kapcsolatot is tükröz. ${ }^{160}$

Ennek köszönhetően a formázástechnológiai vizsgálatokkal nem csupán az edények készítésének módját, hanem a szociális kapcsolatokat is rekonstruálni lehet az elemzett régészeti anyagban. A gyakorlati közösségek struktúrája és szerveződése azonban nagyon változatos lehet, ${ }^{161}$ így a technológiai vizsgálatok önmagukban nem adhatnak választ a szociális kapcsolatok természetére.

A különböző formázási tradíciók tér- és időbeli elterjedése is nagyon változatos lehet. Az európai neolitikumban például a különböző régiókban végzett technológiai vizsgálatok eredményei alapján több, hatalmas területen elterjedt formázási hagyomány jelenlétét feltételezik. ${ }^{162} \mathrm{~A}$ Közel-Keleten pedig egyedülálló módon nagyjából 3500 éven keresztül tartó formázástechnológiai kontinuitást lehetett kimutatni. ${ }^{163}$

\section{A TECHNOLÓGIAI VIZSGÁLAT ALKALMAZÁSA EGY KORA RÉZKORI LELŐHELYEN}

A módszer alkalmazását egy kora rézkori (Kr. e. 4500/44504000) ${ }^{164}$ példán keresztül illusztrálom Tiszagyenda-Vágotthalomról (Nagykunsági-tározó 17. lelőhely). ${ }^{165}$ A lelőhelyet Sebők Katalin vezetésével az ELTE BTK Régészettudományi Intézet, ${ }^{166}$ valamint Polgár Zoltán irányítása alatt a Damjanich János Múzeum munkatársai tárták fel 2010 és 2011 között. A rézkori kerámiaegyüttesben a tiszapolgári, kisrétparti típusú tiszapolgári és bodrogkeresztúri stílus edényei is megtalálhatóak voltak.

A vizsgálati folyamat illusztrálására bemutatom előbb a formázási metódus azonosítását két kiválasztott edényen keresztül, majd pedig a gyakorlati közösségeken belül továbbadódó formázási tradíciók körvonalazását a teljes anyagon tett megfigyelések alapján.

\footnotetext{
${ }^{159}$ Gosselain 2002, 23-27; Roux 2010, 6.

${ }^{160}$ Gosselain-Livingstone SMith 2005, 41-42; Roux 2010, 6; GoMART 2014a, 154; GILIGNY 2015, 73.

${ }^{161}$ Gosselain 2002, 23-27; Roux 2010, 6.

${ }^{162}$ Gomart et al. 2017, 1510, Fig. 7.

${ }^{163}$ VANDIVER 1987, 28.

${ }^{164}$ RACZKY-SiKLósI 2013; Siklósi-SzILÁgyi 2016; SiKLósISzILÁgyi 2021.

${ }^{165}$ SOLNAY in press.

${ }^{166}$ Sево̋K et al. 2018.
} 


\section{A formázási metódus azonosítása}

A formázási metódus azonosításának bemutatásához egyrészt egy díszítetlen, ívelt tálat ${ }^{167}$ választottam példaként, melynek a formájából adódóan három készítési fázisa volt; 1) talp, 2) test és 3) perem. Ezeket azonban nem lehet élesen elkülöníteni. Másrészt egy szintén díszítetlen köcsög ${ }^{168}$ formázási metódusának meghatározását ismertetem, melynek négy készítési fázisa ismert; 1) talp, 2) test, 3) nyak és 4) perem. Az ívelt tállal ellentétben ezek a fázisok - a peremet kivéve - jól elválaszthatók.

A vizsgálat első lépése a makronyomok azonosítása a felület topográfiájának, a falvastagság változásának, a törésvonalak rendszerének és a belső struktúrának a megfigyelésével. A készítési nyomokat egy adatlapon kell rögzíteni, és fotó- és/vagy rajzdokumentációt készíteni róluk. ${ }^{169}$ Mivel a különböző korszakok és régiók kerámiáinak eltérő jellemzői lehetnek (például edényforma, díszítés), vizsgálataimhoz egy egyedi, a kora rézkori leletanyag elemzésére alkalmas adatlapot készítettem (28-30. képek).

A példaként bemutatott ívelt tál (24. kép) belső felületéről hiányoznak a karakterisztikus makronyomok, a külső felületén a test alsó részén ovális alakú fazetták figyelhetők meg. A fal azonos vastagságú, azonban a fazettáknál kiegyenesedik és elvékonyodik. Az edény nagy része egyben megmaradt, csupán két törésvonal figyelhető meg, melyek egyenesek és ívesek, nem figyelhető meg bennük lépcsőzetesség vagy más mintázat. A belső szerkezet homogén, nem mutat egyértelmű mintázatot. Ezek alapján felállítható egy hipotézis az edény formázási metódusáról, mely alapján a kerámiát az elsődleges formázáskor egyetlen agyagpasztatömbből készíthették, feltételezhetően formába nyomással, a másodlagos formázás során pedig az edény külső felületének egy részén ütéstechnikát alkalmaztak.

A makronyomok alapján felállított hipotézist azonban kulcsfontosságú a lehetőségek szerint etnográfiai, régészeti és kísérleti példákkal is alátámasztani. Jelen edény esetében mindhárom kategóriában hozható párhuzam az elsődleges ${ }^{170}$ és másodlagos ${ }^{171}$ formázási technikák referenciájaként, és saját formázási kísérleteket is végeztem (25. kép). Mindezek alátámasztották a makronyomok alapján felállított hipotézist, miszerint az edény formázási metódusa az elsődleges formázáskor formába nyomásból, a másodlagos formázás során ütéstechnikából állt.
A másik példaként bemutatott köcsög (27. kép) külső és belső felületén a talpon és a testen kör és félkör alakú benyomódások, a nyakon pedig bordázat volt megfigyelhető. Az edényfal a talpnál félholdszerüen megvastagodott, a nyakon pedig a fal periodikusan ismétlődő elvékonyodását lehetett azonosítani. A törésvonalak esetében megfigyelhető egyrészt a has kigömbölyödésénél, másrészt a test és a nyak találkozásánál egy-egy vízszintes törésvonal. A belső szerkezet a talpon és a testen kissé hullámzó, de nem mutat egyértelmü mintázatot, míg a nyakon határozott $S-Z$ alakú struktúra rajzolódik ki. Ezek alapján felállítható az edény elsődleges formázási metódusának hipotézise, mely alapján a kerámia testét az elsődleges formázáskor két modellált félgömb összeillesztésével készítették (a két rész találkozási felülete a hasvonalon volt), a nyakat pedig az elsődleges formázáskor váltakozó irányból összeillesztett hurkákból építették fel. Másodlagos formázásra utaló nyom nem volt megfigyelhető.

A makronyomok alapján felállított hipotézist jelen esetben is nélkülözhetetlen volt etnográfiai, régészeti és kísérleti példákkal párhuzamba vonni, melyek ismertek mind a modellálás, ${ }^{172}$ mind a hurkatechnika ${ }^{173}$ esetében. Valamint az edény kapcsán saját formázási kísérleteket is végeztem (26. kép). Így alátámasztható az elsődleges hipotézis az edénytalp és test elsődlegesen két félgömbből modellálásáról, valamint a nyak elsődlegesen hurkatechnikával formázásáról.

\section{Formázási tradíciók és gyakorlati közösségek azonosítása}

Tiszagyendán összesen 72 ép edény vagy töredék volt alkalmas a technológiai vizsgálatokra. Ennek első lépéseként a fent bemutatott módon minden kerámián elvégeztem a makronyomok vizsgálatát és dokumentálását, melyet a formázási hipotézis felállítása, majd etnográfiai, régészeti vagy kísérleti referenciákkal való alátámasztása követett. Így minden edénynek fel lehetett állítani a formázási metódusát, vagyis a formázási müveletek rendezett sorrendjét. Ezt követően különböző csoportokba soroltam az azonos metódussal készült kerámiákat, függetlenül azok egyéb tulajdonságaitól (például formájától vagy díszítésétől). Ezáltal kilenc formázási metódus volt elkülöníthető (1. táblázat).

167Bognár-KutZián 1963, 288-290, Pl. 138; BognÁR-Kutzián 1972, 129, Fig. 25; SZILÁGYi 2015, 78.

${ }^{168}$ BognÁr-KutZián 1963, 276-285, Pl. 135.

${ }^{169}$ GILIGNY 2010, 21; GOMART 2014b, 45.

${ }^{170}$ Huysecom 1994, 39; Gallay 2002, 54; Gosselain 2002, 80; Gelbert 2003, 44; Livingstone SMith 2007, 106-108; Manem 2010, 33; MAYOR 2010, 11, Fig. 2.

${ }^{171}$ Pétrequin-Pétrequin 1996, 87; Martineau 2000, 138; Kreiter et al. 2007, 120; Ard 2010, 40; Doosselaere 2010, 263; Manem 2010, 33; Gomart 2014a, 147; Gomart 2014b, 280, Tab. 81.

\footnotetext{
${ }^{172}$ Smith-Crépeau 1983, 58-60; Frank 1993, 388; Gosselain 2002, 93-100; Livingstone Smith 2007, 101-102; Manem 2010, 33; Mayor 2010, 11, Fig. 2.

${ }^{173}$ Martineau 2000; Gosselain 2002, 101-112; Bosquet et al. 2005; Gucsi 2006; Livingstone Smith 2007, 102-104; Silva 2008, 226; MANEM 2010, 32-34; Gallay 2012, 297-306; Gomart 2014a; Gomart 2014b, 280, Tab. 81; Giligny 2015; FÜZESI 2019, 91-92.
} 
1. táblázat. Tiszagyenda-Vágott-halom kora rézkori anyagában azonosított formázási metódusok

Tab. 1. The identified forming methods in the Early Copper Age ceramic assemblage of Tiszagyenda-Vágott-halom

\begin{tabular}{|c|c|c|c|c|c|c|}
\hline \multirow[t]{2}{*}{$\begin{array}{l}\text { Formázási } \\
\text { metódus }\end{array}$} & \multirow[t]{2}{*}{ Darabszám } & \multicolumn{5}{|c|}{$\begin{array}{c}\text { Formázás } \\
\text { (amennyiben az adott edény tipológiája relevánssá teszi) }\end{array}$} \\
\hline & & Csótalp & Talp & Test & Nyak & Perem \\
\hline 1. metódus & $\begin{array}{c}34 \mathrm{db} \\
(5 \mathrm{db}-\text { nak } \\
\text { csak a nyaka } \\
\text { ismert) }\end{array}$ & $\begin{array}{l}\text { Elsódleges } \\
\text { formázás: } \\
\text { hurkatechnika: } \\
\text { S-Z alak }\end{array}$ & $\begin{array}{l}\text { Elsődleges } \\
\text { formázás: } \\
\text { hurkatechnika }\end{array}$ & $\begin{array}{l}\text { Elsődleges } \\
\text { formázás: } \\
\text { hurkatechnika: } \\
\text { 1) befelé ferde, } \\
\text { 2) S-Z alak }\end{array}$ & $\begin{array}{l}\text { Elsődleges } \\
\text { formázás: } \\
\text { hurkatechnika: } \\
\text { 1) befelé ferde, } \\
\text { 2) kifelé ferde, } \\
\text { 3) S-Z alak }\end{array}$ & $\begin{array}{l}- \\
\text { (nem } \\
\text { diagnosztikus) }\end{array}$ \\
\hline 2. metódus & $1 \mathrm{db}$ & - & $\begin{array}{l}\text { Elsődleges } \\
\text { formázás: } \\
\text { hurkatechnika }\end{array}$ & $\begin{array}{l}\text { Elsődleges } \\
\text { formázás: } \\
\text { hurkatechnika: } \\
\text { ismeretlen alak } \\
\text { Másodlagos } \\
\text { formázás: } \\
\text { ütéstechnika }\end{array}$ & $\begin{array}{l}\text { Elsődleges } \\
\text { formázás: } \\
\text { hurkatechnika: } \\
\text { befelé ferde }\end{array}$ & $\begin{array}{l}\text { - } \\
\text { (nem } \\
\text { diagnosztikus) }\end{array}$ \\
\hline 3. metódus & $1 \mathrm{db}$ & - & $\begin{array}{l}\text { Elsődleges } \\
\text { formázás: } \\
\text { hurkatechnika }\end{array}$ & $\begin{array}{l}\text { Elsődleges } \\
\text { formázás: } \\
\text { egy darab, } \\
\text { széles lapból készült } \\
\text { Másodlagos } \\
\text { formázás: } \\
\text { kaparás kívül }\end{array}$ & - & $\begin{array}{l}\text { - } \\
\text { (nem } \\
\text { diagnosztikus) }\end{array}$ \\
\hline 4. metódus & $3 \mathrm{db}$ & - & \multicolumn{2}{|c|}{$\begin{array}{l}\text { Elsődleges formázás: } \\
\text { modellálás, a talp és a test egyben }\end{array}$} & - & $\begin{array}{l}- \\
\text { (nem } \\
\text { diagnosztikus) }\end{array}$ \\
\hline 5. metódus & $8 \mathrm{db}$ & - & \multicolumn{2}{|c|}{$\begin{array}{l}\text { Elsődleges formázás: } \\
\text { modellálás, a talp és a test egyben }\end{array}$} & $\begin{array}{l}\text { Elsődleges } \\
\text { formázás: } \\
\text { hurkatechnika: } \\
\text { 1) befelé ferde, } \\
\text { 2) S-Z alak }\end{array}$ & $\begin{array}{l}\text { Elsődleges } \\
\text { formázás: } \\
\text { hurkatechnika: } \\
\text { befelé ferde } \\
\text { (csak egy } \\
\text { edényen } \\
\text { diagnosztikus) }\end{array}$ \\
\hline 6. metódus & $7 \mathrm{db}$ & - & \multicolumn{2}{|c|}{$\begin{array}{l}\text { Elsődleges formázás: } \\
\text { laptechnika, a talp és a test egyben }\end{array}$} & - & $\begin{array}{l}- \\
\text { (nem } \\
\text { diagnosztikus) }\end{array}$ \\
\hline 7. metódus & $3 \mathrm{db}$ & - & \multicolumn{2}{|c|}{$\begin{array}{l}\text { Elsődleges formázás: } \\
\text { formába nyomás, a talp és a test egyben }\end{array}$} & - & $\begin{array}{l}- \\
\text { (nem } \\
\text { diagnosztikus) }\end{array}$ \\
\hline 8. metódus & $14 \mathrm{db}$ & - & \multicolumn{2}{|c|}{$\begin{array}{l}\text { Elsődleges formázás: } \\
\text { formába nyomás, a talp és a test egyben }\end{array}$} & - & $\begin{array}{l}\text { Elsődleges } \\
\text { formázás: } \\
\text { hurkatechnika: } \\
\text { 1) befelé ferde, } \\
\text { 2) S-Z alak }\end{array}$ \\
\hline 9. metódus & $1 \mathrm{db}$ & - & \multicolumn{2}{|c|}{$\begin{array}{l}\text { Elsődleges formázás: } \\
\text { formába nyomás, a talp és a test egyben } \\
\text { Másodlagos formázás: ütéstechnika }\end{array}$} & - & $\begin{array}{l}\text { - } \\
\text { (nem } \\
\text { diagnosztikus) }\end{array}$ \\
\hline
\end{tabular}




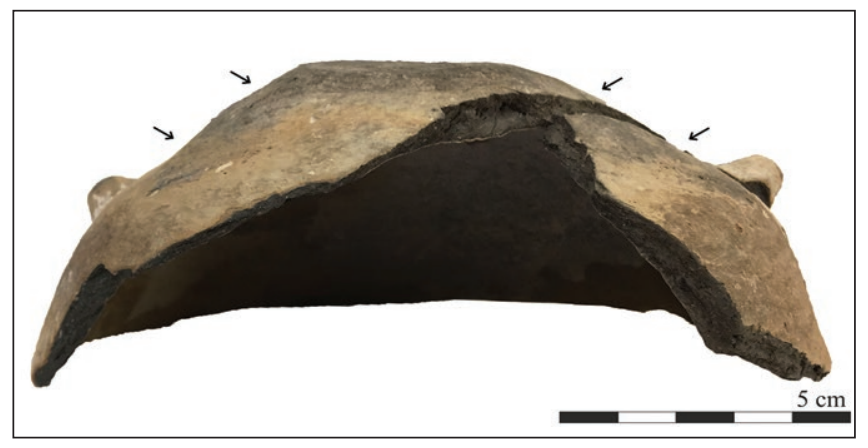

22. kép. A fazettáknál kiegyenesedő fal (Tiszagyenda-Vágott-halom)

Fig. 22. Straightening wall at the facets (Tiszagyenda-Vágott-halom)

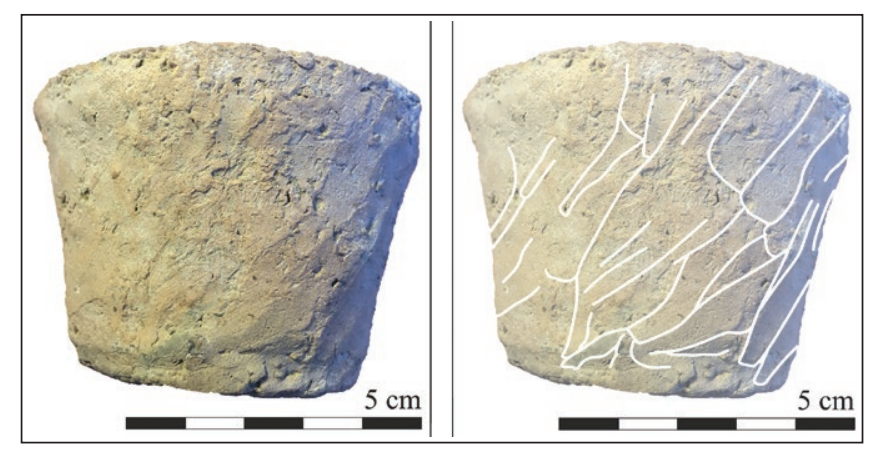

23. kép. Lapocskák az edény horizontális felületén (Tiszagyenda-Vágotthalom)

Fig. 23. Flat areas on the horizontal surface (Tiszagyenda-Vágott-halom)

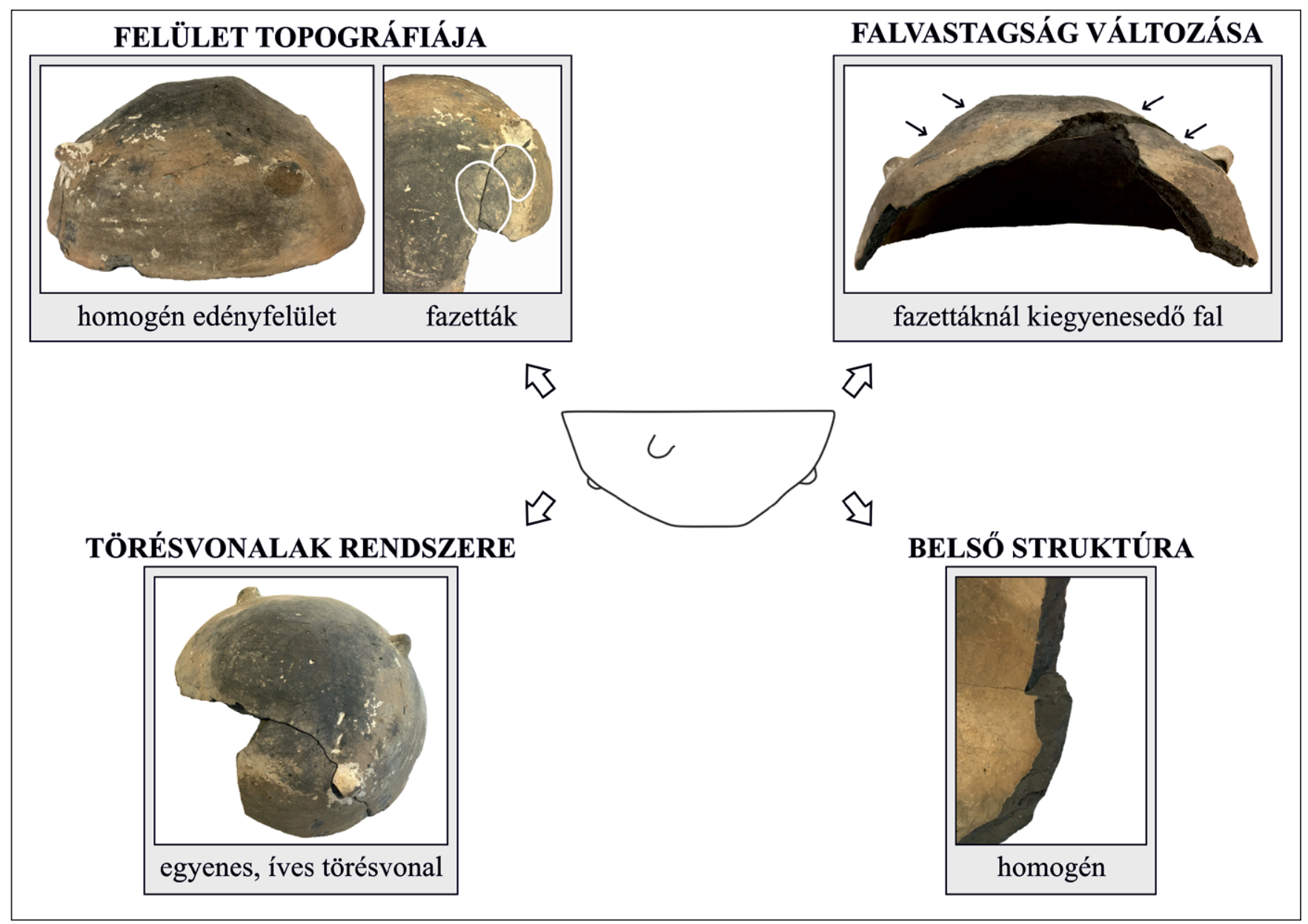

24. kép. A makronyomok azonosításának bemutatása egy Tiszagyenda-Vágott-halomról előkerült kora rézkori ívelt tálon

Fig. 24. The identification of the macrotraces on a spherical bowl from Tiszagyenda-Vágott-halom 


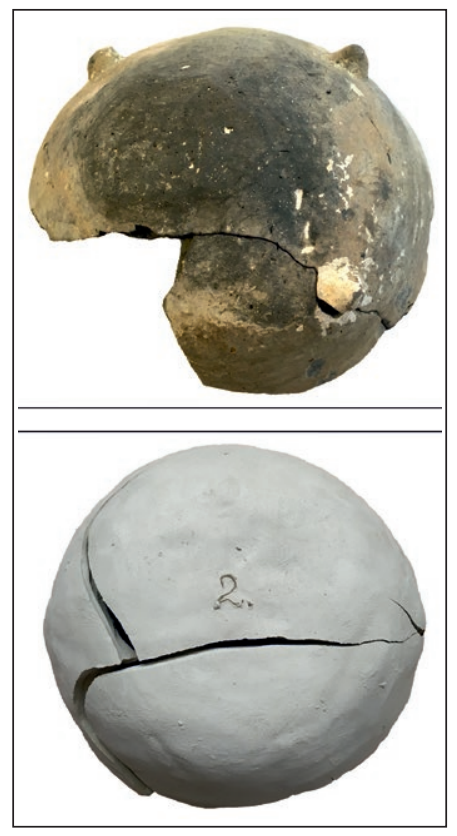

25. kép. A vizsgált ívelt tál és a kísérleti edény

Fig. 25. The analyzed spherical bowl and the experimental vessel

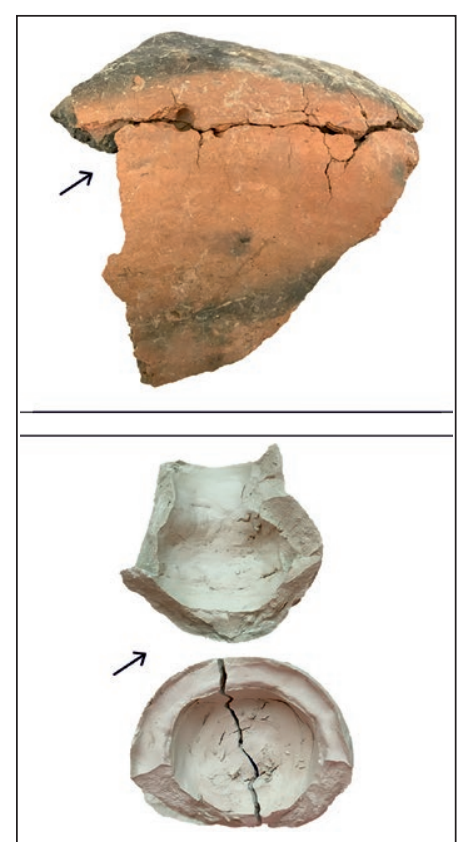

26. kép. A vizsgált köcsög és a kísérleti edény

Fig. 26. The analyzed jug and the experimental vessel

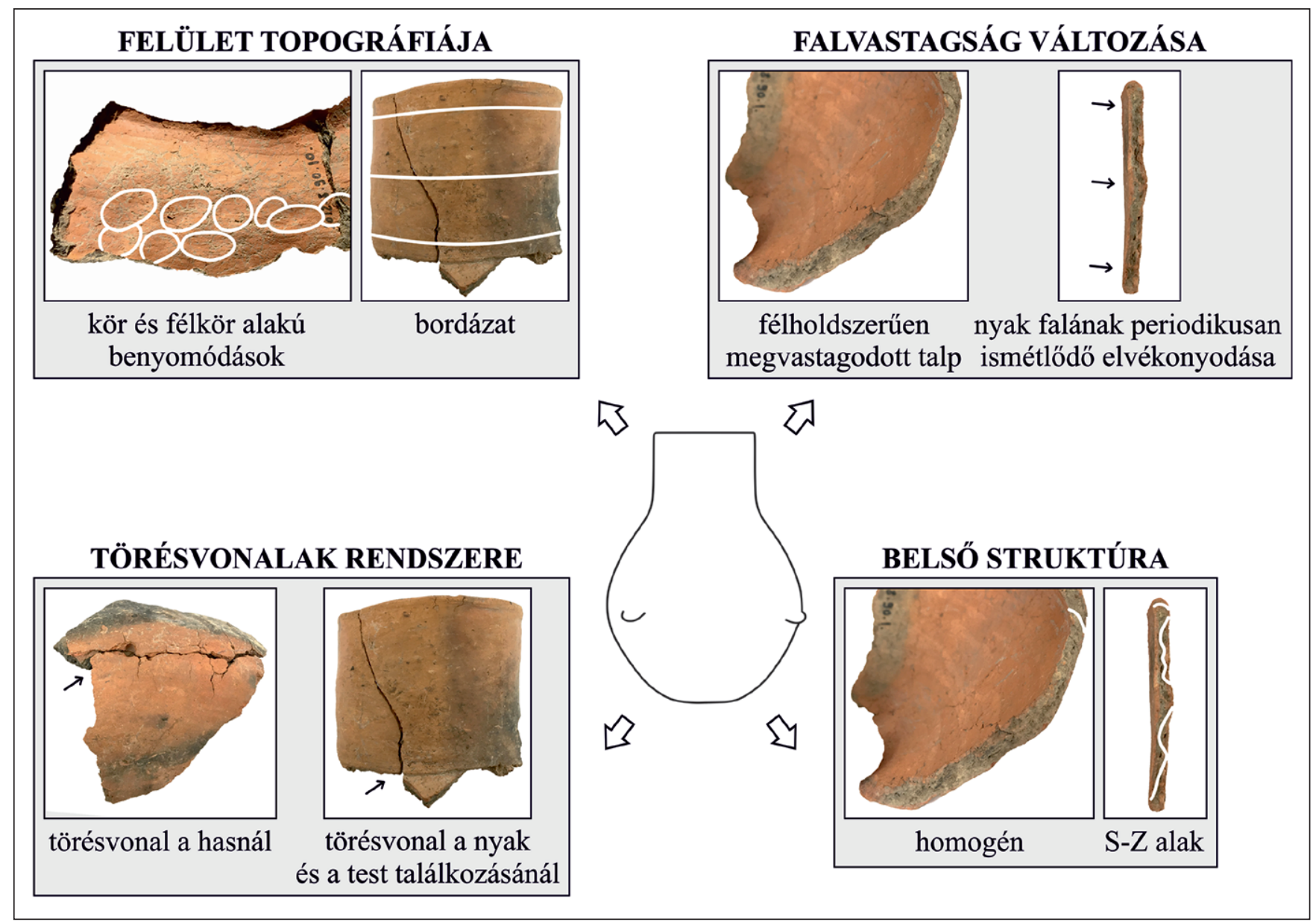

27. kép. A makronyomok azonosításának bemutatása egy Tiszagyenda-Vágott-halomról előkerült kora rézkori köcsögön

Fig. 27. The identification of the macrotraces on a jug from Tiszagyenda-Vágott-halom 
$\mathrm{Az}$ 1. metódusba olyan edények kerültek, melyeknek minden ismert formázási fázisát az elsődleges formázás során hurkatechnikával készítették, ${ }^{174}$ másodlagos formázást pedig nem lehetett megfigyelni.

A 2. metódusba tartozó egyetlen edényt az 1. metódushoz hasonlóan elsődlegesen hurkatechnikával készítették, azonban a másodlagos formázáskor a test bizonyos részein ütéstechnikát alkalmaztak a végső alak megformálásához. ${ }^{175}$

A 3. metódusba szintén egyetlen edény tartozott, melyet feltételezhetően hurkából felépített talpból, ${ }^{176}$ majd egyetlen, széles hurkalapból álló testből készíthettek az elsődleges formázás során. Ezt követően pedig a másodlagos formázás során az egész edénytest külső felületét végigkaparták. ${ }^{177}$

A 4. metódusba tartozó edényeket elsődlegesen egyetlen agyaggolyóból, modellálással formázhatták. ${ }^{178}$ Másodlagos formázásra utaló nyomot nem lehetett azonosítani.

$\mathrm{Az}$ 5. metódushoz sorolható edények talpát és testét a 4. metódushoz hasonlóan az elsődleges formázáskor egyetlen agyaggolyóból formázták, azonban erre a nyak, illetve a perem ${ }^{179}$ kialakítása érdekében hurkákat helyeztek. Másodlagos formázás itt sem volt azonosítható. Ide tartozik a korábban részletesen bemutatott köcsög is.

A 6. metódusba tartozó edényeket feltételezhetően elsődlegesen laptechnikával készíthették, ${ }^{180}$ másodlagos formázásra utaló makronyom nem volt megfigyelhető.

A 7. metódussal készült edényeket egyetlen agyagpasztatömb formába nyomásával készíthették, ${ }^{181}$ azonosítható másodlagos formázás nélkül.

A 8. metódusba olyan edényeket lehetett csoportosítani, melyek talpát és testét az elsődleges formázás során a 7. metódushoz hasonlóan formába nyomással készítették, azonban erre a perem kialakítása érdekében hurkákat illesztettek. ${ }^{182}$ Másodlagos formázás itt sem volt azonosítható.

${ }^{174}$ Martineau 2000; BosQuet et al. 2005; Gosselain 2002, $101-$ 112; Livingstone Smith 2007, 102-104; Silva 2008, 226; Manem 2010, 32-34; Gallay 2012, 297-306; Gomart 2014a; Gomart 2014b, 280, Tab. 81; GILIGNy 2015, 75-78.

${ }^{175}$ PÉtrequin-PÉtrequin 1996, 87; Martineau 2000, 138 ; Kreiter et al. 2007, 120; Ard 2010, 40; Doosselaere 2010, 263; Manem 2010, 33; Gomart 2014a, 147; Gomart 2014b, 280, Tab. 81.

${ }^{176}$ Manem 2008, 28; Silva 2008, 224, Fig. 4; Doosselaere 2010, 258; Giligny 2010, 23-24; Gomart 2014b, 280, Tab. 81.

${ }^{177}$ Gosselain 2002, 115-117; Berg 2008, 1182; Doosselaere 2010, 280-281; Gallay 2012, 316, 321-322.

${ }^{178}$ Frank 1993, 388; Gosselain 2002, 93-100; Livingstone SMith 2007, 101-102; Manem 2010, 33; Mayor 2010, 11, Fig. 2.

${ }^{179}$ Gosselain 2002, 96.

${ }^{180}$ VANDIVER 1987.

${ }^{181}$ Huysecom 1994, 39; Gallay 2002, 54; Gosselain 2002, 80; Gelbert 2003, 44; Livingstone Smith 2007, 106-108; Manem 2010, 33; MAYOR 2010, 11, Fig. 2.

${ }^{182}$ Gosselain 2002, 89; Gelbert 2003, 44; Livingstone Smith 2007, 107.
A 9. metódussal kizárólag a korábban részletesen bemutatott ívelt tál készült, melyet az elsődleges formázáskor a 7. és 8. metódusokhoz hasonlóan formába nyomással készítettek, majd a másodlagos formázás során ütéstechnikával alakították ki az edény végső formáját.

$\mathrm{Az}$ azonosított formázási metódusok kilenc formázási tradíciót jeleznek, melyek a kora rézkori fazekasok közötti folyamatos tudásátadás lenyomataként értelmezhetőek. Az edényformázás különböző módjainak továbbadása ekkor is gyakorlati közösségeken belül történhetett, melyeket számunkra ismeretlen jellegü és természetü szociális kapcsolat köthetett össze.

A lelőhely kerámiaanyagának teljes értelmezéséhez elengedhetetlen volt a tipológia vizsgálata. Tiszagyendán számos edényformát lehetett azonosítani, azonban ezek egy részére mindig egyféle formázási metódus volt jellemző. ${ }^{183}$ Csupán két forma készítésében lehetett egymástól gyökeresen eltérő formázási hagyományokat felfedezni; a tálak és a nyakas edények esetében. A tálak egy részét az elsődleges formázás során mindig laptechnikával (7. metódus), a másikat viszont formába nyomással (8., 9. és 10. metódus) készíthették. A nyakas edények egy csoportjának talpát és testét pedig az elsődleges formázás során kizárólag hurkatechnikával (1. és 2. metódus), a másik csoportját pedig modellálással (5. metódus) építhették fel.

Ezek alapján feltételezhető, hogy a kora rézkori lelőhelyen többféle, átfogó formázási tradícióegyüttes létezett, melyeknek lehettek közös (virágcserép alakú edények, kétfülü csészék és csőtalpas tálak készítése) és eltérő (tálak és nyakas edények készítése) elemeik. Ez arra utal, hogy a vizsgált kerámiaanyag készítése mögött több gyakorlati közösség tudásátadási folyamata állhatott, melyek formázási hagyományai részben megegyezhettek, ami valamiféle - talán korábbi időszakból eredő - közös tudást feltételez. Ennek vizsgálatára további lelőhelyek kerámiaanyagának technológiai elemzésére lesz szükség. Bizonyos edényformák esetében azonban gyökeresen más készítési tradíciók hagyományozódhattak a közösségeken belül, mely talán összefügg ezen edénytípusok olykor speciális, rituális funkciójával. A tálak és a nyakas edények ugyanis domináns darabjai a korszak sírkerámiáinak, melyek közül néhány edényformát, például a tejesköcsög alakú edényeket, ${ }^{184}$ leggyakrabban rituális jellegü együttesekben tártak fel, a hétköznapi környezethez köthető leletanyagban kevésbé. Ezt a hipotézist szintén további kerámiaegyüttesek analízisével lehetne megbízhatóan alátámasztani vagy cáfolni.

${ }^{183}$ Például a virágcserép alakú edényekre (BognÁR-KutZián 1963, 240-242, 271-274, Pl. 123 és 137-138; BognÁR-Kutzián 1972, 121; Szilágyi 2015, 80), kétfülü csészékre (Patay 1974, 25; SZILÁGYi 2015, 81) vagy a csőtalpas tálakra (BogNÁR-KutZIÁN 1963, 248-257, Pls 127-128; SZILÁGyi 2015, 82).

${ }^{184}$ SZILÁGYi 2015, 317-318. 


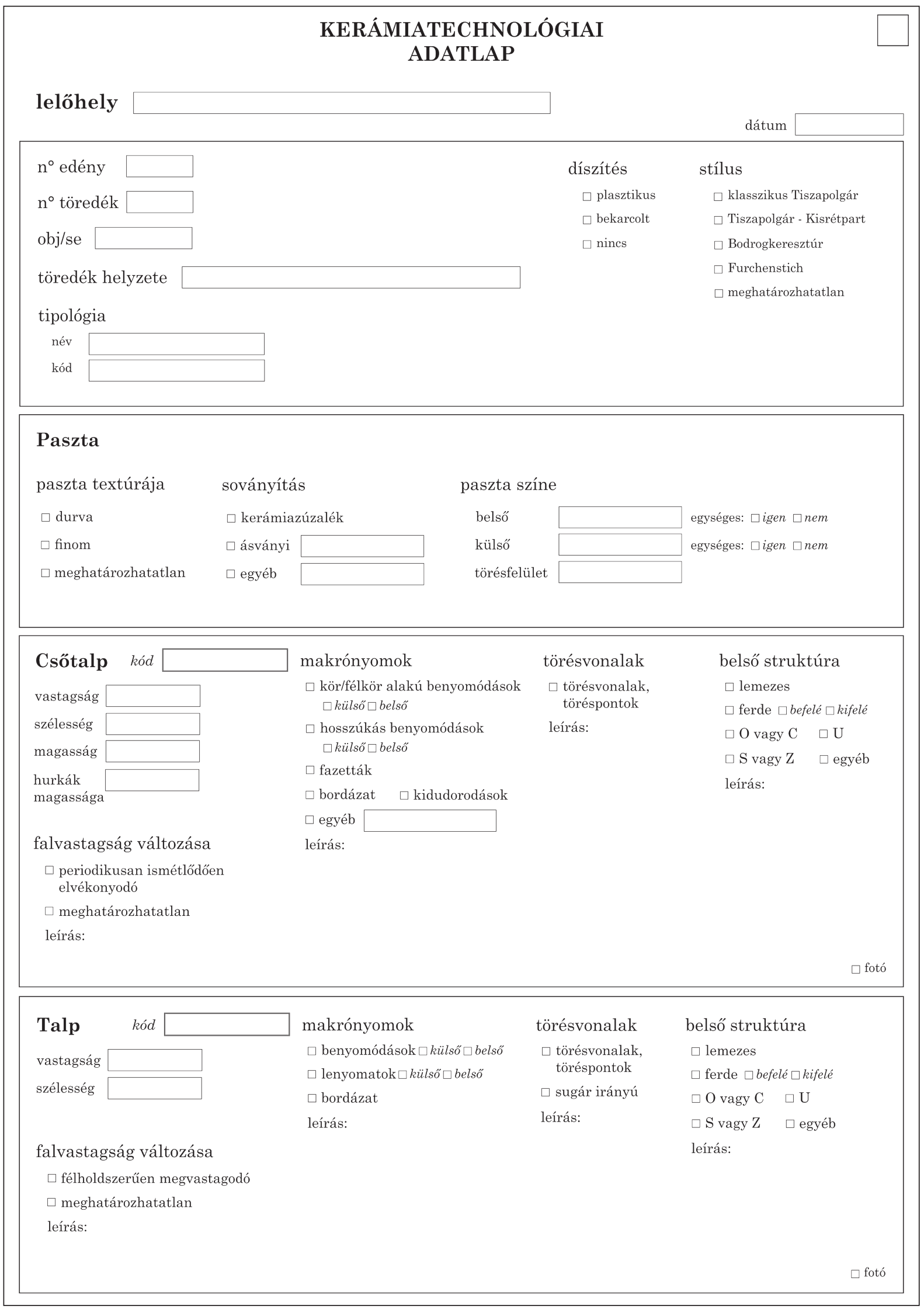

28. kép. A vizsgálataimhoz készített egyedi, a kora rézkori leletanyag formázástechnológiai elemzésére alkalmas adatlap - 1. oldal

Fig. 28. Unique data sheet prepared for the fashioning technological analysis of Early Copper Age ceramic assemblages - Page 1 


\section{lelöhely \\ $\mathrm{n}^{\circ}$ edény \\ $\mathrm{obj} / \mathrm{se}$}

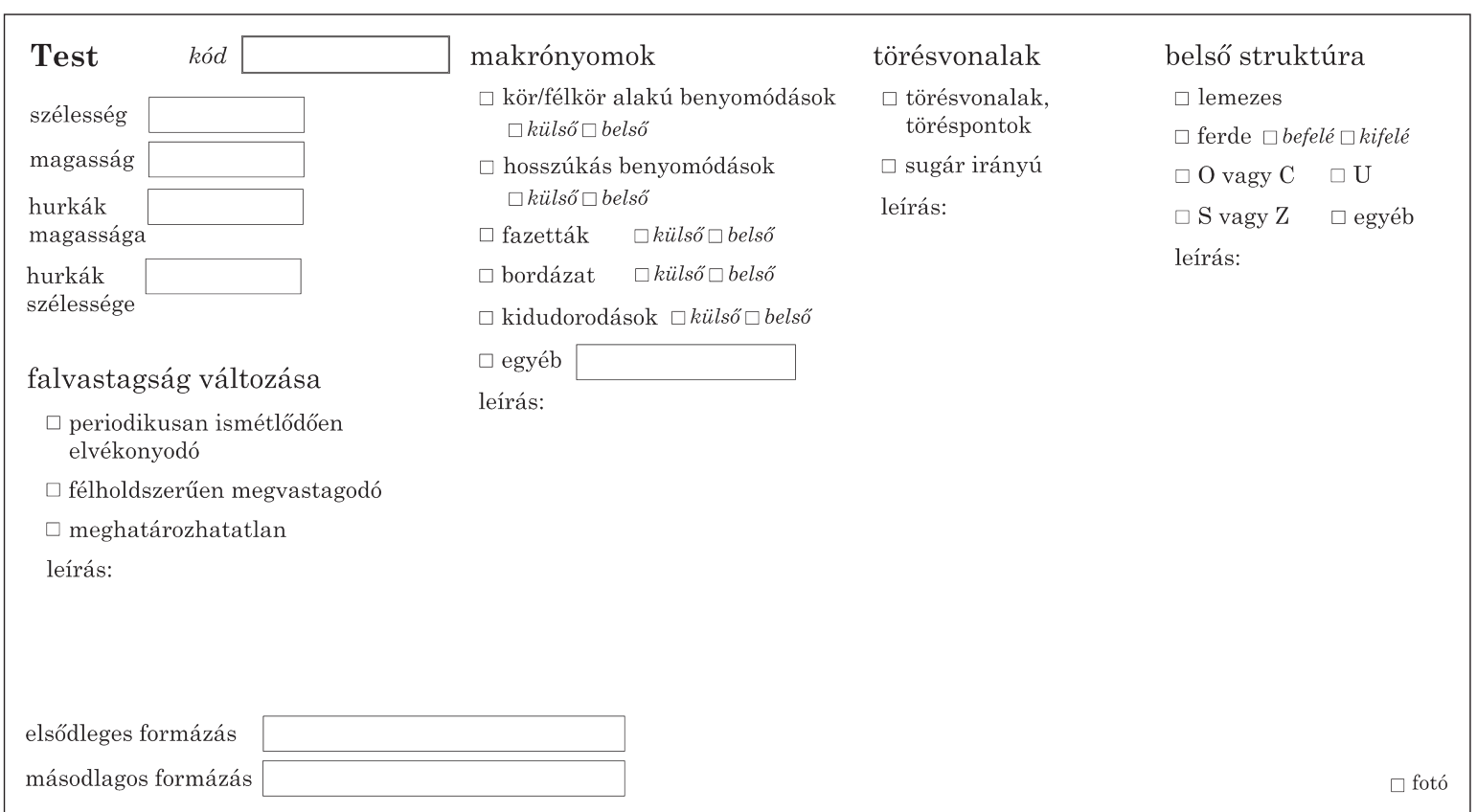

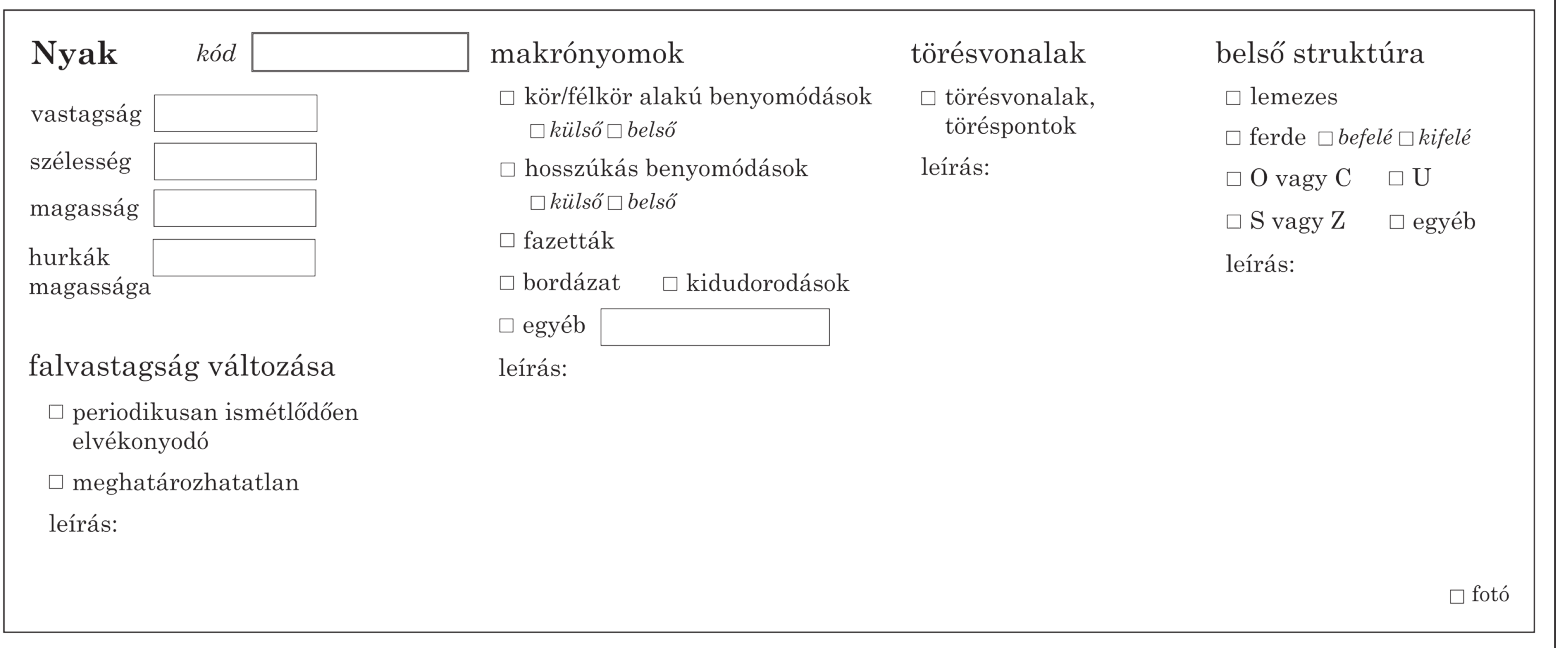

\begin{tabular}{|c|c|c|c|c|c|}
\hline Perem & kód & makrónyomok & törésvonalak & \multirow{3}{*}{$\begin{array}{l}\text { belsô struktúra } \\
\square \text { lemezes } \\
\square \text { ferde } \square \text { befelé } \square \text { kifelé } \\
\square \text { O vagy C }\end{array}$} & \\
\hline \multirow{5}{*}{$\begin{array}{l}\text { vastagság } \\
\text { szélesség }\end{array}$} & & \multirow[t]{5}{*}{ leírás: } & \multirow{5}{*}{$\begin{array}{l}\square \text { törésvonalak, } \\
\text { töréspontok } \\
\text { leírás: }\end{array}$} & & \multirow{5}{*}{$\begin{array}{l}\square \mathrm{U} \\
\square \text { visszahajlított } \\
\square \text { befelé } \square \text { kifelé } \\
\square \text { egyéb }\end{array}$} \\
\hline & & & & & \\
\hline & & & & & \\
\hline & & & & $\square$ S vagy $Z$ & \\
\hline & & & & leírás: & \\
\hline
\end{tabular}

29. kép. A vizsgálataimhoz készített egyedi, a kora rézkori leletanyag formázástechnológiai elemzésére alkalmas adatlap - 2. oldal

Fig. 29. Unique data sheet prepared for the fashioning technological analysis of Early Copper Age ceramic assemblages - Page 2 


lelöhely $\square$
$\mathrm{n}^{\circ}$ edény $\square$
obj/se $\square$

Rajz

30. kép. A vizsgálataimhoz készített egyedi, a kora rézkori leletanyag formázástechnológiai elemzésére alkalmas adatlap - 3. oldal

Fig. 30. Unique data sheet prepared for the fashioning technological analysis of Early Copper Age ceramic assemblages - Page 3 


\section{ÖSSZEGZÉS}

A kerámiák formázásának technológiai vizsgálata tehát egy olyan antropológiai megközelítésű módszer, mely az edények aprólékos vizsgálatával, illetve etnográfiai, régészeti és kísérleti referenciák felhasználásával képes formázási tradíciókat azonosítani, melyek szociális alapon szerveződő gyakorlati közösségeken belül adódhattak tovább. ${ }^{185}$ Így a módszertan lehetőséget nyújt a régészeti korokban olyan hosszú távú kapcsolati pályák azonosítására, melyek szociális kapcsolatokkal hozhatók összefüggésbe.

A módszer egyik nagy előnye, hogy számos régészeti anyagon alkalmazható, függetlenül annak korától vagy helyétől, ${ }^{186}$ köszönhetően a formázási technikák univerzális jellemzőinek. Ez lehetőséget ad számos régészeti probléma feltárására, mint például a vizsgált időszak szociális összefüggései, vagy a hagyományos régészeti kultúrák és a szociális kapcsolatok viszonya.

\section{KÖSZÖNETNYILVÁNÍTÁS}

Mindenekelőtt szeretném megköszönni Siklósi Zsuzsannának sokéves töretlen támogatását és állandó segítségét. Iránymutatása segített rávilágítani jelen kutatási módszertan fontosságára és alkalmazásának jelentőségére. Támogatása nélkül ez a tanulmány nem készülhetett volna el. Köszönöm Szilágyi Mártonnak, Sebők Katalinnak, Polgár Zoltánnak és Hajdú Zsigmondnak a Tiszagyenda-Vágott-halom és Polgár-Király-ér-part lelőhelyek feldolgozásának lehetőségét. Továbbá köszönöm Louise Gomart folytonos segítségét és magyarázatait mind a kutatási módszer elsajátításában, mind a régészeti anyagok vizsgálatában. Illetve szeretném hálámat kifejezni François Gilignynek a módszertan elsajátításáért és a kutatási eredményeim revíziójáért. Végül, de nem utolsósorban, szeretném megköszönni Mester Zsolt megjegyzéseit és segítségét a módszertani áttekintés és a francia kifejezések fordításának pontosítása kapcsán.

A tanulmány az Innovációs és Technológiai Minisztérium ÚNKP-20-2 kódszámú Új Nemzeti Kiválóság Programjának a Nemzeti Kutatási, Fejlesztési és Innovációs Alapból finanszírozott szakmai támogatásával készült.

\section{IRODALOM}

ARD, VinCENT

2010 Analyse technologique de céramiques provenant d'enceintes fossoyées du Néolithique récent du centre-ouest de la France attribuées au groupe Vienne-Charente (3500-2900 av. J.-C.). Les nouvelles de l'Archéologie 119, 37-41.

Arnold, DeAn E.

2006 The Threshold Model for Ceramic Resources: A Refinement. In: Gheorgiu, D. (ed.): Ceramic Studies. Papers on the social

${ }^{185}$ Gosselain-Livingstone Smith 2005, 41-42; Roux 2010, 6; Gomart 2014a, 154; Giligny 2015, 73.

${ }^{186} \mathrm{Az}$ itt bemutatott vizsgálati módszertan elsősorban a korongolatlan edények kutatására vonatkozik. and cultural significance of ceramics in Europe and Eurasia from prehistoric to historic times. Archaeological Reports International Series 1553. Oxford, 3-9.

Audouze, Françoise-Karlin, Claudine

2017 La chaîne opératoire a 70 ans: qu'en ont fait les préhistoriens français. Journal of Lithic Studies (Edinburgh) 4/2, 5-73. http://journals.ed.ac.uk/lithicstudies/article/view/2539/3751 (Utolsó elérés: 2021. 07. 14.) DOI: https://doi.org/10.2218/jls. v4i2.2539

BALFET, HÉLÈNE

1953 Notes sur le façonnage des poteries préhistoriques. Bulletin de la société préhistorique française 50/4, 211-217.

1965 Ethnographical Observations in North Africa and Archaeological Interpretation: the Pottery of the Maghreb. In: Matson, F. R. (dir.): Ceramics and Man. New York, 161-177.

1966 La céramique comme document archéologique. Bulletin de la Société préhistorique française (Paris) 63, 279-310.

1975 Technologie. In: Creswell, R. (dir.): Éléments d'ethnologie. Six Approches. Vol. 2. Paris, 44-80.

1977 Poterie féminine et poterie masculine au Maghreb. Thèse d'Etat en Ethnologie, Université de Paris V, manuscrit.

1991 Des chaînes opératoires, pour quoi faire? In: Balfet, H. (dir.): Observer l'action technique: des chaînes opératoires, pour quoi faire? Paris, 11-20.

BERG, INA

2008 Looking through pots: recent advances in ceramics X-radiography. Journal of Archaeological Science 35, 11771188. DOI: https://doi.org/10.1016/j.jas.2007.08.006

BogNÁR-KUTZIÁN, IDA

1963 The Copper Age Cemetery of Tiszapolgár-Basatanya. Archaeologica Hungarica 42. Budapest.

1972 The Early Copper Age Tiszapolgár Culture in the Carpathian Basin. Archaeologica Hungarica 48. Budapest.

Bosquet, Dominique-Fock, Heike-Livingstone Smith, Alexandre 2005 La chaîne opératoire de la céramique rubannée: Première tentetive de la réconstruction. In: Livingstone Smith, A.Bosquet, D.-Martineau, R. (eds): Pottery Manufacturing Processes: Reconstitution and Interpretation. Actes du XIVème Congrès UISPP de Liège, Belgique, 2-8 septembre 2001. British Archaeological Reports - International Series 1349. Oxford, 103-114.

BRIL, BLANDINE

2002 Lapprentissage de gestes techniques: ordre de contraintes et variations culturelles. In: Bril, B.-Roux, V. (eds): Le geste technique. Réflexions méthodologiques et anthropologiques. Revue d'Anthropologie des connaissances, Technologies / Idéologies / Pratiques. Ramonville Saint-Agne, 113-150.

Cresswell, Robert

1976 Techniques et Cultures. Les bases d'un programme de travail. Techniques et Cultures 1, 7-59.

Delage, Christophe

2017 Once upon a time... the (hi)story of the concept of the chaine opératoire in French prehistory. World Archaeology 49/2, 158173. DOI: https://doi.org/10.1080/00438243.2017.1300104

Doosselaere, Barbara van

2010 Poterie et histoire au temps des grands empires ouest-africains: Etude technologique de l'assemblage céramique de Koumbi Saleh (Mauritanie, 6e-17e siècle). Thèse de doctorat, Université de Paris I Panthéon-Sorbonne, manuscrit.

Dupont-Delaleuf, Armance

2010 Les chaînes opératoires de la céramique d'UlugDépé (Turkménistan). Du Chalcolithique moyen à la période achéménide. Les nouvelles de l’Archéologie 119, 47-51. 
Frank, Barbara E.

1993 Reconstructing the History of an African Ceramic Tradition: Technology, Slavery and Agency in the Région of Kadiolo (Mali). Cahiers détudes africaines 131/33, 381-401.

FüZESI, ANDRÁs

2019 A késő neolitikus edények megformálásának technikai jellegzetességei - Öcsöd-Kováshalom leletegyüttese alapján. In: Vice, M.-Kovács, G. (szerk.): M $\Omega \mathrm{MO} \Sigma$ X. Öskoros Kutatók X. Összejövetelének konferenciakötete, Öskori technikák, őskori technológiák Százhalombatta, 2017. április 6-8. Százhalombatta, 84-109.

Gallay, Alain

1992 A propos de la céramique actuelle du delta intérieur du Niger (Mali): approche ethnoarchéologique et règles transculturelles. In: Gallay, A.-Audouze, F.-Roux, V. (eds): Ethnoarchéologie: Justification, Problèmes, Limites. Juan-les-Pins, 67-90.

2002 Étude ethnoarchéologique des traditions céramiques du pays Dogon: rapport de la mission Février 2002. Genève.

2012 Potières du Sahel: à la découverte des traditions céramiques de la Boucle du Niger (Mali). Gollion.

Gelbert, Agnès

2003 Traditions céramiques et emprunts techniques dans la vallée du fleuve Sénégal. Ceramic traditions and technical borrowings in the Senegal River Valley. Paris.

Gibson, Alex-Woods, Anne

1997 Prehistoric pottery for the archaeologist. Leicester.

Giligny, François

1993 La variabilité des récipients céramiques au Chalcolithique moyen-récent jurassien (3400-2400 av. J.-C.). Analyse archéologique d'un système d'objets. Thèse de doctorat de l'Université de Paris 1, manuscrit.

2010 Reconstitution des techniques de fabrication de la céramique néolithique dans le Bassin parisien. Les Nouvelles de l'Archéologie 119, 20-25. DOI: https://doi.org/10.4000/nda.961

2015 Воссоздание технологии изготовления керамики неолита парижского бассейна: научное мнение. Reconstruction of the process techniques of the Neolithic pottery in Paris Basin: a research assessment. Самарский научный вестник. Samara Journal of Science 12/3, 72-89. DOI: https://doi.org/10.17816/ snv20153206

GoMART, Louise

2010 Méthodes détude technologique de corpus céramiques issus de contextes détritiques. Le cas des vases retrouvés en contexte d'habitat rubané dans la vallée de l'Aisne. Les nouvelles de l'Archéologie 119, 25-29. DOI: https://doi.org/10.4000/nda.963

2014a Quels facteurs démergence du premier Néolithique d'Europe tempérée? Apports de l'approche anthropologique d'assemblages céramiques du Néolithique ancien et moyen de Hongrie. / What factors of emergence of the first Neolithic in temperate Europe? Contribution of the anthropological approach of ceramic assemblages from the early and middle Neolithic in Hungary. Annales de la Fondation Fyssen 29, 143160 .

2014b Traditions techniques et production céramique au Néolithique ancien. Étude de huit sites rubanés du nord est de la France et de Belgique. Leiden.

Gomart, Louise-Anders, Alexandra-Kreiter, Attila-Marton, Tibor-Oross, Krisztián-RACZky, PÁL

2020 Innovation or inheritance? Assessing the social mechanisms underlying ceramic technological change in early Neolithic pottery assemblages in Central Europe. In: Spataro, M.Furholt, M. (eds): Detecting and explaining. Technological Innovation in Prehistory. Leiden, 49-70.
Gomart, Louise-Weiner, Allon-Gabriele, Marzia-Durrenmath, Gilles-Sorin, Sabine-Angeli, Lucia-Colombo, MartaFabbri, Cristina-Maggi, Roberto-Panelli, Chiara-Pisani, Didier F.-Radi, Giovanna-Tozzi, Carlo-Binder, Didier

2017 Spiralled patchwork in pottery manufacture and the introduction of farming to Southern Europe. Antiquity 91/360, 1501-1514. DOI: https://doi.org/10.15184/aqy.2017.187

Gomart, Louise-Anders, Alexandra-Kreiter, Attila-Marton, Tibor-Oross, Krisztián-Raczky, PÁL

2020 Innovation or inheritance? Assessing the social mechanisms underlying ceramic technological change in early Neolithic pottery assemblages in Central Europe. In: Spataro, M.Furholt, M. (eds): Detecting and explaining. Technological Innovation in Prehistory. Leiden, 49-70.

Gosselain, Olivier P.

1992 Technology and Style: Potters and Pottery Among Bafia of Cameroon. Man - New Series 27/3, 559-586.

2002 Poteries du Cameroun méridional: Styles techniques et rapports à l'identité. Monographie du Collection de Recherches Archéologiques 26. Paris.

2010 Ethnographie comparée des trousses à outils de potiers au sud du Niger. Bulletin de la Société préhistorique française 107, 667-690.

Gosselain, Olivier P.-Livingstone Smith, Alexandre

2005 The source: Clay selection and processing practices in subSaharan Africa. In: Livingstone Smith, A.-Bosquet, D.Martineau, R. (eds): Pottery Manufacturing Processes: Reconstitution and Interpretation. Actes du XIVème Congrès UISPP de Liège, Belgique, 2-8 septembre 2001. British Archaeological Reports - International Series 1349. Oxford, 33-44.

GuCSI, LÁSZLó

2000 Kerámiatechnológiai megfigyelések a badeni kultúra leletein. A Wosinszky Mór Múzeum Évkönyve 22, 89-99.

2006 Rézkori és kora bronzkori kerámiákon végzett technikai megfigyelések. In: Holló, Sz. A.-Szulovszky, J. (szerk.): Az agyagművesség évezredei a Kárpát-medencében. BudapestVeszprém 2006, 7-18.

2009 The manufacturing techniques of the grave pottery from Budakalász. In: Bondár, M.-Raczky, P. (eds): The Copper Age cemetery of Budakalász. Budapest, 449-456.

GuCSI, LÁsZló-SZABó, Nóra

2018 Examination and possible interpretations of a Middle Bronze Age structured deposition. Dissertationes Archaeologicae 3/6, 217-285. DOI: https://doi.org/10.17204/dissarch.2018.217

Holló, Zsolt-Lengyel, György-Mester, Zsolt

2001 Egy pattintott kőeszköz életútja. Magyar kifejezések a technológiai vizsgálatokhoz 1 . Ösrégészeti Levelek 3, 51-57.

HuYSECOM, ERIC

1994 Identification technique des céramiques africaines. In: Courtin, J.-Binder, D. (dir.): Terre cuite et Société. La céramique, document technique, économique, culturel. XIVe Rencontres Internationales d'Archéologie et d'Histoire d'Antibes. Juan-lesPins, 31-44.

Kreiter, Attila

2007 Technological choices and material meanings in Early and Middle Bronze Age Hungary: understanding the active role of material culture through ceramic analysis. British Archaeological Reports - International Series 1604. Oxford.

Kreiter, Attila-Marton, Tibor-Gomart, Louise-Oross, KrisztiánPÁNCZÉL, PÉTER

2017 Looking into houses: analysis of LBK ceramic technological change on a household level - Regard à l'intérieur des 
maisonnées: une analyse des changements dans les techniques céramiques LBK à l'échelle domestique. In: Burnez-Lanotte, L. (ed.): Matières à Penser: Raw materials acquisition and processing in Early Neolithic pottery productions - Matières à penser: sélection et traitement des matières premières dans les productions potières du Néolithique ancien. Paris, 111-132.

Latour, Bruno-Lemonnier, Pierre

1994 De la préhistoire aux missiles balistiques. L'intelligence sociale des techniques. Paris.

LEMONNIER, PIERRE

1983 Létude des systèmes techniques, une urgence en technologie culturelle. Techniques et Culture 1, 11-34.

1991 De la culture matérielle à la culture? Ethnologie des techniques et Préhistoire. In: Perlès, C. (dir.): 25 ans d'études technologiques en Préhistoire: bilan singulier et perspectives, (actes des XIe Rencontres internationales d'Archéologie et d'Histoire d'Antibes, 18-20 oct. 1990). Juans-les-Pins, 15-34.

LEPÈRE, CÉDRIC

2014 Experimental and traceological approach for a technical interpretation of ceramic polished surfaces. Journal of Archaeological Science 46, 144-155. DOI: https://doi. org/10.1016/j.jas.2014.03.010

Leroi-Gourhan, ANDré

1943 Évolution et techniques. Evolution et techniques (Vol. 1). Paris.

1945 Évolution et techniques. Milieu et technique (Vol. 2). Paris.

1964 Le geste et la parole. Technique et langage (Vol. 1). Paris.

1965 Le geste et la parole. La mémoire et les rythmes (Vol. 2). Paris.

Livingstone Smith, Alexandre

2007 Chaîne opératoire de la poterie. Références ethnographiques, analyses et reconstitution. Musée royal de l'Afrique centrale. Tervuren 2007.

2010 Reconstitution de la chaîne opératoire de la poterie. Bilan et perspectives en Afrique sub-saharienne. Les nouvelles de l'Archéologie 119, 9-21. DOI: https://doi.org/10.4000/nda.955

Livingstone Smith, Alexandre-Visseyrias, Aline

2010 Shaping Kabambian Pottery: Identification and Definition of Technical Features. The Open Anthropology Journal 3, 124141.

MAget, MARCEL

1953 Guide d'étude directe de comportements culturels. Paris.

MANEM, SÉBASTIEN

2008 Les fondements technologiques de la culture des Duffaits (âge du bronze moyen). Thèse de doctorat, Université Paris 10 Nanterre, manuscrit.

2010 Des habitats aux sites de rassemblement a vocation rituelle: lâge du Bronze selon le concept de «chaîne opératoire». Les nouvelles de l'Archéologie 119, 30-36. DOI: https://doi. org/10.4000/nda.965

MARTINEAU, RÉMI

2000 Poterie, techniques et sociétés: études analytiques et expérimentales à Chalain et Clairvaux (Jura), entre 3200 et 2900 av. J.-C. Thèse de doctorat de l'Université de FrancheComté, manuscrit.

2010 Brunissage, polissage et degrés de séchage. Un référentiel expérimental. Les nouvelles de l’Archéologie 119, 13-19. DOI: https://doi.org/10.4000/nda.959

Marton, Tibor-Kreiter, Attila-FüZesi, András-Gomart, LouiseGortva, Gergely-Gucsi, LÁszló-Oross, Krisztián-Pető, ÁkosSerlegi, GÁbor-M. VirÁg, ZsuzsannA-Jakucs, János

2020 Változó tradíciók. A kerámiastílus, -előállítás és -használat tér- és időbeli mintázatai a Kr. e. 6. évezred második felében a Délkelet-Dunántúlon és a környező régiókban. Magyar Régészet 2020 Tavasz, 1-11. http://real.mtak.hu/107938/1/ Marton_H20TA.pdf (Utolsó elérés: 2021. 03. 26.)
Mauss, Marcel

1947 Manuel d'ethnographie. Paris.

2000 A test technikái. In: Mauss, M. [Fejős, Z. (szerk.)]: Szociológia és antropológia. Budapest, 423- 446.

MAYOR, ANNE

2010 Ceramic Traditions and Ethnicity in the Niger Bend, West Africa. Ethnoarchaeology 2/1, 5-48. DOI: https://doi. org/10.1179/eth.2010.2.1.5

Méry, Sophie-Dupont-Delaleuf, Amance-Van der Leeuw, Sander

2010 Analyse technologique et expérimentations. Les techniques de façonnage céramique mettant en jeu la rotation à Hili (Émirats arabes unis) à la fin du IIIe millénaire (âge du Bronze ancien). Les nouvelles de l'Archéologie 119, 52-58. DOI: https://doi. org/10.4000/nda.973

Mester, Zsolt

2019 A műveletsortól a technikai rendszerig: a paleoetnológiai szemlélet hasznossága a technológiai kutatásban. In: Vice, M.Kovács, G. (szerk.): $\mathrm{M} \Omega \mathrm{MO} \Sigma \mathrm{X}$. Öskoros Kutatók X. Összejövetelének konferenciakötete Öskori technikák, őskori technológiák Százhalombatta, 2017. április 6-8. Százhalombatta, 255-270.

Orton, Clive-Tyers, Paul-Vince, Alan

1993 Pottery in archaeology. Cambridge.

PATAY PÁL

1974 Die hochkupferzeitliche Bodrogkeresztúr-Kultur. Bericht der Römisch-Germanischen Kommission 55, 1-71.

Pellegrin, Jacques-Karlin, Claudine-Bodu, Pierre

1988 „Chaîne opératoires”: un outil pour le préhistorien. In: Tixier, J. (dir.): Journée deétudes technologiques en préhistoire. Notes et monographies techniques 25. Paris, 55-62.

Pétrequin, Anne-Marie-Pétrequin, Pierre

1999 La poterie en Nouvelle Guinée: savoirfaire et transmission des techniques. Journal de la Société des océanistes 108/1, 71-101.

Pierret, Alain

2002 Analyse technologique des céramiques archéologiques: développements méthodologiques pour l'identification des techniques de façonnage. Un exemple d'application: le matériel du village des Arènes à Levroux (Indre). Villeneuve d'Ascq.

RACZKY, PÁL-SiKLÓSI, ZsUZSANNA

2013 Reconsideration of the Copper Age Chronology of the Eastern Carpathian Basin. Antiquity. 87/336, 555-573. DOI: https:// doi.org/10.1017/S0003598X00049127

Rice, Prudence M.

1987 Pottery analysis. A sourcebook. Chicago-London.

Roux, VALENTINe

1994 La technique du tournage: définition et reconnaissance par les macrotraces. In: Courtin, J.-Binder, D. (dir.): Terre cuite et Société. La céramique, document technique, économique, culturel. XIVe Rencontres Internationales d'Archéologie et d'Histoire d'Antibes. Juan-les-Pins, 45-58.

2010 Lecture anthropologique des assemblages céramiques. Les Nouvelles de l'Archéologie 119, 4-9. DOI: https://doi. org/10.4000/nda.957

2017 Des céramiques et des hommes: Décoder les assemblages archéologiques. Paris-Nanterre.

2019 Ceramics and Society: A Technological Approach to Archaeological Assemblages. Cham.

RYE, OWEN S.

1981 Pottery technology: principles and reconstruction. Washington.

Sebők, Katalin-Szilágyi, Márton-VÁcZi, GÁbor

2018 Tiszagyenda, Vágott-halom. In: Kisfaludi, J.-Kvassay, J.Kreiter, A. (szerk.): Régészeti kutatások Magyarországon 2010. Budapest, 380-381. 
ShePARd, AnNa O.

1956 Ceramics for the Archaeologist. Washington.

SiKLÓsi ZsuzsanNA-SZILÁGYi MÁRTON

2016 Módszertani, interpretációs kérdések az alföldi rézkor radiokarbon keletkezése kapcsán. Tisicum - A Jász-NagykunSzolnok Megyei Múzeumok Évkönyve 25, 65-72.

2021 Culture, Period or Style? Reconsideration of Early and Middle Copper Age Chronology of the Great Hungarian Plain. Radiocarbon 63/2, 1-62. DOI: https://doi.org/10.1017/ RDC.2020.115

Silva, FabíOla ANDRÉA

2008 Ceramic Technology of the Asurini do Xingu, Brazil: An Ethnoarchaeological Study of Artifact Variability. Journal of Archaeological Method and Theory 15, 217-265. DOI: https:// doi.org/10.1007/s10816-008-9054-8

Smith, Philip E. L.-Crépeau, Robert

1983 Fabrication expérimentale de répliques d'un vase néolithique du site de Ganj Dareh, Iran: recherche technologique. Paléorient 9/2, 55-62.

SOFAER, JOANNA-BUDDEN, SANDY

2013 Many hands make light work: potting and embodied knowledge at the Bronze Age tell at Százhalombatta, Hungary. In: Stig Sørensen, M. S.-Rebay-Salisbury, K (eds): Embodied Knowledge. Perspectives on Belief and Technology. Oxford, 117-127.

SOLNAY, EsZTER

in press Kora rézkori edények formázásának technológiai vizsgálata Tiszagyenda-Vágott-halom lelőhelyének kerámiaegyüttesében.
Tisicum - A Jász-Nagykun-Szolnok megyei múzeumok évkönyve, in press.

SzAKMÁnY, GYörgy-NAgy, ANNA

2017 Kerámiák petrográfiai mikroszkópos vizsgálata: megfigyelések és értelmezés. In: Ridovics, A.-Bajnóczi, B.-Dági, M.-Lővei, P. (szerk.): Interdiszciplinaritás. Archeometriai, régészeti és művészettörténeti tanulmányok. Budapest, 249-261.

SZILÁGYi, MÁRTON

2015 Kora rézkori településszerkezet a Közép-Tisza-vidéken. Doktori disszertáció, Eötvös Loránd Tudományegyetem, kézirat.

VAN DER LEEUW, SANDER

1993 Giving the Potter a Choice. Conceptual aspects of pottery techniques. In: Lemonnier, P. (ed.): Technological choices: transformation in material cultures since the Neolithic. London-New York, 238-288.

VANDIVER, PAMELA

1987 Sequential Slab Construction; A Conservative Southwest Asiatic Ceramic Tradition, ca. 7000-3000 B.C. Paléorient 13/2, 9-35.

Visseyrias, Aline

2010 Élément de puzzle ou de cadavre exquis? Une vision du façonnage des céramiques archéologiques non tournées. Les nouvelles de l'Archéologie 119, 42-46. DOI: https://doi. org/10.4000/nda.969 


\section{Technological analysis of ceramic fashioning: A review of the methodological basis and their application}

\section{Eszter Solnay}

There is a potter behind every handmade pottery, who shaped the vessel based on its mental representation, using his knowledge and skills. As a result, each pottery carries some traces which refer to the cognitive and motor habits of the potter. The technological analysis of ceramic fashioning is based on this ascertainment.

This approach aims to identify the techniques and methods of fashioning through the analysis of the macrotraces on the vessels, which are the imprints of the forming process. Thus, ceramic fashioning sequences can be identified, which can shed light on real social dynamics. That is because the fashioning sequences are resistant to change, contrary to the typology and style ${ }^{187}$ since the forming gestures become "motor habits" during the learning process, which always takes place within communities of practice with the involvement of a socially related tutor and a learner. ${ }^{188}$ Therefore, the technical traditions of ceramic fashioning transmitted within the communities of practices of different sociological natures, whose trajectories can be tracked over space and time. $^{189}$
The analysis focuses on the macroscopic features of the ceramics, which must be interpreted based on several experimental, archaeological, and ethnographic reference works. ${ }^{190}$ Thus, techniques and methods of fashioning will be identified. For the successful realization of this analytical approach, the methodology and the French and English nomenclature must be translated into Hungarian. This includes the expressions of the examination process, the name and meaning of the various primary and secondary forming techniques - such as the coiling technique, modeling (i. e. pinching or drawing), molding, hammering, beating, and scraping - and the nomenclature of their characteristic macrotraces.

This methodological overview based on the technological analysis of ceramic fashioning of two Early Copper Age sites: Tiszagyenda-Vágott-halom (Nagykunsági-tározó, Site 17) and Polgár-Király-ér-part (Polgár 1, Site 1). Moreover, the resume of the technological examination of the ceramic assemblage of Tiszagyenda-Vágott-halom presents the realization of the methodological approach from the analysis of the macrotraces to the identification of technical traditions.

\footnotetext{
${ }^{187}$ Gelbert 2003, 53-59; Gosselain 2002, 26.

${ }^{188}$ Gosselain 2002, 23-27; Roux 2010, 4, 6.

${ }^{189}$ Giligny 2015, 73; Gomart 2014a, 154; Gosselain-LivingSTONe SMith 2005, 41-42; Roux 2010, 6.
}

${ }^{190}$ Doosselaere 2010, 223; Gelbert 2003, 15; Giligny 2010, 21;
Gomart 2014a, 146; Smith-CréPeau 1983.

Open Access. A cikk a Creative Commons Attribution 4.0 International License (https://creativecommons.org/licenses/by/4.0) feltételei szerint publikált Open Access közlemény, melynek szellemében a cikk bármilyen médiumban szabadon felhasználható, megosztható és újraközölhetô, feltéve, hogy az eredeti szerző és a közlés helye, illetve a CC License linkje és az esetlegesen végrehajtott módosítások feltüntetésre kerülnek. (SID_1) 